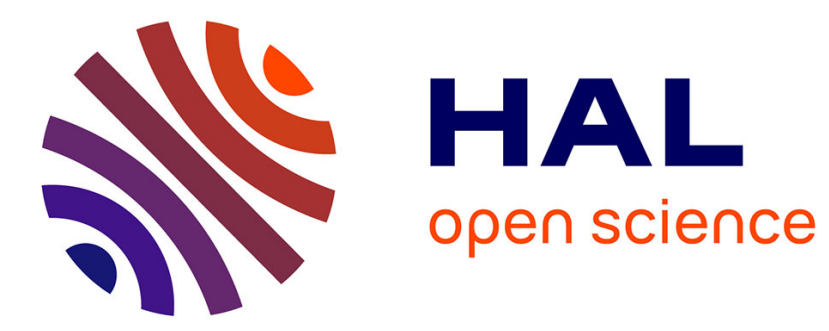

\title{
ppGpp influences protein protection, growth and photosynthesis in Phaeodactylum tricornutum
}

Luisana Avilan, Régine Lebrun, Carine Puppo, Sylvie Citerne, Stephane

Cuine, Benoît Menand, Yonghua Li-Beisson, Ben Field, Brigitte Gontero

\section{To cite this version:}

Luisana Avilan, Régine Lebrun, Carine Puppo, Sylvie Citerne, Stephane Cuine, et al.. ppGpp influences protein protection, growth and photosynthesis in Phaeodactylum tricornutum. New Phytologist, In press, 230 (4), pp.1517-1532. 10.1111/nph.17286 . hal-02903690v2

\section{HAL Id: hal-02903690 \\ https://hal.science/hal-02903690v2}

Submitted on 20 Mar 2021

HAL is a multi-disciplinary open access archive for the deposit and dissemination of scientific research documents, whether they are published or not. The documents may come from teaching and research institutions in France or abroad, or from public or private research centers.
L'archive ouverte pluridisciplinaire HAL, est destinée au dépôt et à la diffusion de documents scientifiques de niveau recherche, publiés ou non, émanant des établissements d'enseignement et de recherche français ou étrangers, des laboratoires publics ou privés. 


\section{ppGpp influences protein protection, growth and photosynthesis in Phaeodactylum tricornutum}

\section{Luisana Avilan ${ }^{1,2}$ (D), Regine Lebrun ${ }^{3}$, Carine Puppo ${ }^{1}$, Sylvie Citerne ${ }^{4}$, Stephane Cuiné ${ }^{5}$, Yonghua Li-Beisson ${ }^{5}$ (D), Benoît Menand $^{6}$ (D) Ben Field ${ }^{6}$ (D) and Brigitte Gontero ${ }^{1}$}

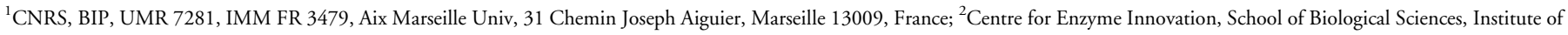
Biological and Biomedical Sciences, University of Portsmouth, Portsmouth, PO1 2DY, UK; ${ }^{3}$ Plate-forme Protéomique, Marseille Protéomique (MaP), IMM FR 3479 , 31 Chemin Joseph

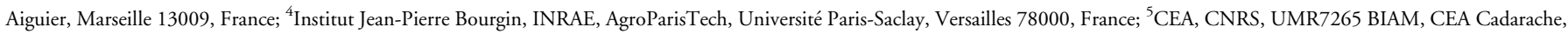
Aix-Marseille Univ, Saint-Paul-lez Durance 13108, France; ${ }^{6}$ CEA, CNRS, UMR7265 BIAM, Aix-Marseille Univ, Marseille 13009, France

Authors for correspondence: Ben Field

Email: ben.field@univ-amu.fr

Brigitte Gontero

Email: bmeunier@imm.cnrs.fr

Received: 25 August 2020

Accepted: 8 February 2021

New Phytologist (2021)

doi: $10.1111 / \mathrm{nph} .17286$

Key words: chloroplast, diatoms, lipid droplets, Phaeodactylum tricornutum, photosynthesis, ppGpp, proteome.

\section{Summary}

- Chloroplasts retain elements of a bacterial stress response pathway that is mediated by the signalling nucleotides guanosine penta- and tetraphosphate ((p)ppGpp). In the model flowering plant Arabidopsis, ppGpp acts as a potent regulator of plastid gene expression and influences photosynthesis, plant growth and development. However, little is known about ppGpp metabolism or its evolution in other photosynthetic eukaryotes.

- Here, we studied the function of ppGpp in the diatom Phaeodactylum tricornutum using transgenic lines containing an inducible system for $\mathrm{ppGpp}$ accumulation. We used these lines to investigate the effects of ppGpp on growth, photosynthesis, lipid metabolism and protein expression.

- We demonstrate that $\mathrm{ppGpp}$ accumulation reduces photosynthetic capacity and promotes a quiescent-like state with reduced proliferation and ageing. Strikingly, using nontargeted proteomics, we discovered that ppGpp accumulation also leads to the coordinated upregulation of a protein protection response in multiple cellular compartments.

- Our findings highlight the importance of ppGpp as a fundamental regulator of chloroplast function across different domains of life, and lead to new questions about the molecular mechanisms and roles of ( $\mathrm{p}$ )ppGpp signalling in photosynthetic eukaryotes.

\section{Introduction}

Diatoms are a group of unicellular eukaryotic photosynthetic organisms that form a major part of phytoplankton, and are responsible for up to one-fifth of net global carbon fixation (Falkowski et al., 2000). Beside their ecological importance, diatoms are also studied because they have a wide range of potential applications that include drug delivery in chemotherapy, biofuels and as environmental indicators for monitoring water quality (Levitan et al., 2014; Lavoie et al., 2017; Uthappa et al., 2018).

Diatoms appeared relatively recently in evolutionary history, around 200 million years ago (Medlin, 2016; Benoiston et al., 2017). The diatom chloroplast was acquired through complex endosymbiotic events, where it is thought that a red algal ancestor was engulfed by a eukaryote that already possessed green algal genes from a previous endosymbiosis (Dorrell et al., 2017). The acquisition of additional genes by lateral gene transfer from bacteria is also likely to have been an important driving force in the evolution of diatoms (Bowler et al., 2008). These complex origins confer a unique cellular physiology to diatoms that allows them to adapt to multiple environments (Vardi et al., 2008; Gruber \& Kroth, 2017).

The diatom chloroplast differs in a number of aspects from the chloroplast of plants and green algae. At the level of membrane architecture, the diatom chloroplast is surrounded by four membranes, and the thylakoids are loosely stacked with three interconnected membranes (Flori et al., 2017). Moreover, the lightharvesting complex (LHC) of diatoms is known as the fucoxanthin-chlorophyll protein complex (FCP), and is composed of tetramers containing $\mathrm{Chl} c$ and the carotenoid fucoxanthin (Lepetit et al., 2012; Roding et al., 2018; Nagao et al., 2019; Pi et al., 2019). Diatoms have other specific features such as a functional urea cycle (Allen et al., 2011) and a eukaryotic EntnerDoudoroff glycolytic pathway (Fabris et al., 2012), and they lack the plastid oxidative pentose phosphate pathway found in plants (Gruber \& Kroth, 2017). The regulation of diatom metabolism is also distinct from that in plants (Jensen et al., 2017; Launay et al., 2020).

Like plants, diatoms possess signalling pathways with prokaryotic origins such as the bacterial histidine-kinase-based two-component systems (Bowler et al., 2008), as well as pathways of 
eukaryotic origins such as the target of rapamycin (TOR) kinase (Prioretti et al., 2017) and the G protein-coupled receptor signalling pathway (Port et al., 2013).

Another signalling pathway that could play an important role in diatom stress acclimation is the pathway mediated by the nucleotides guanosine tetraphosphate and guanosine pentaphosphate ((p)ppGpp) (Field, 2018; Avilan et al., 2019; Prioretti et al., 2020). In bacteria, ppGpp and, to a lesser extent, pppGpp accumulate in response to a range of different stresses, and specifically target transcription and translation to slow growth and promote stress acclimation (Hauryliuk et al., 2015; Steinchen \& Bange, 2016). (p)ppGpp is also found in plants and green algae (Takahashi et al., 2004), and chloroplast-targeted enzymes related to the E.coli RelA / SpoT (p)ppGpp synthetases are widespread among the photosynthetic eukaryotes (Atkinson et al., 2011; Ito et al., 2017; Avilan et al., 2019). Currently, the function of ppGpp is best characterized in the flowering plant Arabidopsis, where it inhibits chloroplast gene expression, reduces chloroplast size and reduces photosynthetic capacity (Maekawa et al., 2015; Sugliani et al., 2016; Honoki et al., 2018). While the mechanisms are still uncertain, ppGpp may act by downregulating the transcription of chloroplast-encoded genes via the inhibition of chloroplastic RNA polymerases or GTP biosynthesis (Nomura et al., 2014; Yamburenko et al., 2015; Sugliani et al., 2016). Concentrations of ppGpp increase in response to different abiotic stresses, as well as in response to treatment with stress-associated plant hormones (Takahashi et al., 2004). Increased ppGpp concentrations can affect growth under nitrogen-limiting conditions (Maekawa et al., 2015; Honoki et al., 2018) and plant immune signalling (Abdelkefi et al., 2018).

Genes coding for RelA SpoT Homolog (RSH) enzymes are present in all fully sequenced photosynthetic eukaryotes (Field, 2018; Avilan et al., 2019). However, very little is known about the role of (p)ppGpp in algae, and in particular in algae of the red lineage. A recent study in the extremophile red alga Cyanidioschyzon merolae showed that overexpression of CmRSH4b, a functional (p)ppGpp synthetase, results in a reduction in chloroplast size and decreased chloroplast rRNA transcription, although (p)ppGpp concentrations were not measured (Imamura et al., 2018). The situation in diatoms, with their mixed red-green heritage and specific lifestyles, is even less clear. A recent analysis showed that the nuclear genome of the marine diatom Phaeodactylum tricornutum encodes three functional RSH enzymes from red lineage-specific clades: PtRSH1, a bifunctional (p)ppGpp synthetase/hydrolase; and PtRSH4a and PtRSH4b, which act exclusively as (p)ppGpp synthetases (Avilan et al., 2019). Here, we studied (p)ppGpp signalling in P. tricornutum by manipulating endogenous ppGpp concentrations using transgenic lines that express a bacterial (p)ppGpp synthetase under the control of an inducible promoter. The use of a distantly related bacterial enzyme reduces the possibility of regulatory feedback that could occur using endogenous RSH enzymes. We found that ppGpp accumulation led to a reduction in photosynthetic capacity and an inhibition of ageing and growth. Strikingly, a proteomic analysis revealed that ppGpp accumulation also leads to the robust activation of a protein protection response involving chaperones and proteases. Our findings demonstrate that core ppGpp signalling is highly conserved across the photosynthetic eukaryotes, and that ppGpp has species-specific roles that may be linked to adaptation to particular environments and lifestyles.

\section{Materials and Methods}

\section{Cell culture}

Phaeodactylum tricornutum Bohlin (strain name Pt1_8.6; RCC 2967) was obtained from Roscoff Culture Collection. Cells were grown in f/2 medium (Guillard \& Ryther, 1962) without silica and adjusted to $\mathrm{pH}$ 8. The medium contained either $0.88 \mathrm{mM}$ $\mathrm{NaNO}_{3}\left(\mathrm{f} / 2-\mathrm{NO}_{3}\right)$ or $\mathrm{NH}_{4} \mathrm{Cl}\left(\mathrm{f} / 2-\mathrm{NH}_{4}\right)$ as a nitrogen source. Cultures in liquid medium in Erlenmeyer flask or on agar plates ( $2 \%$ bacto-agar) were maintained at $18^{\circ} \mathrm{C}$ under continuous illumination $\left(30 \mu \mathrm{mol}\right.$ photon $\left.\mathrm{m}^{-2} \mathrm{~s}^{-1}\right)$ with LED lamps. Samples for cell counting (Malassez counting chamber) and protein extraction were withdrawn from liquid cultures.

\section{Plasmid construction and transformation of $P$. tricornutum}

The vector pPha-NR carrying the nitrate reductase promoter and the ble gene for zeocin resistance (Chu et al., 2016) (GenBank accession number JN180663, kindly provided by Prof. P. Kroth), was used as backbone for all plasmid constructions. The DNA fragments used for gene fusion and cloning in the final constructs were amplified by PCR using Q5 DNA polymerase (New England Biolabs, Evry, France) under standard conditions. The primers are specified in Supporting Information Table S1. The amplified fragments were assembled in the vector, previously digested with EcoRI and HindIII, by the sequence and ligation independent cloning (SLIC) method (Jeong et al., 2012).

The genes coding for a (p)ppGpp synthetase (SYN) and an inactive mutant form $(D 275 G)$ of this synthetase $\left(S Y N^{D>G}\right)$ were obtained by PCR, using plasmids described in Sugliani et al. (2016) as templates. SYN corresponds to the (p)ppGpp synthetase RelA from E. coli (residue 1 to 386). To target the enzymes to the chloroplast, the genes were fused by PCR to the sequence coding for the bipartite targeting sequence of the chloroplastic gamma ATP synthetase of P.tricornutum (GeneBank accession number U29898) whose ability to target proteins to the chloroplast is well characterized (Apt et al., 2002; Liu et al., 2016). A Kozak sequence (AAG) was included in the primer before the ATG translation start site to facilitate translation. The final constructions were used to transform cells by particle bombardment as previously described (Falciatore et al., 1999; Kroth, 2007). Full details of the transformation procedure are provided in Methods S1. Multiple independent transgenics lines were used for each construction in subsequent experiments.

\section{Nucleotide determination}

Guanosine triphosphate (GTP) and ppGpp concentrations were determined using stable isotope labelled internal standards as 
described (Bartoli et al., 2020). Briefly, $8 \mathrm{mg}$ (DW equivalent) of $P$. tricornutum cells were harvested from cultures at $2 \mathrm{~d}$ after induction and nucleotides were directly extracted with $3 \mathrm{ml} 2 \mathrm{M}$ formic acid containing 12.5 pmol ${ }^{13} \mathrm{C}$-labelled ppGpp and 125 pmol ${ }^{13} \mathrm{C}$-labelled GTP. Extracts were incubated on ice for $30 \mathrm{~min}$, then $3 \mathrm{ml} 50 \mathrm{mM}$ ammonium acetate at $\mathrm{pH} 4.5$ was added; samples were then loaded onto pre-equilibrated Oasis WAX SPE cartridges and nucleotides were eluted with a mixture of methanol/water $/ \mathrm{NH}_{4} \mathrm{OH}(20: 70: 10)$. The eluates were lyophilized and resuspended in water before analysis by high-performance liquid chromatography (HPLC)-MS/MS with multiple reaction monitoring. The quantification of (p)ppGpp in Fig. 1(c) was hindered by poor detection of the ${ }^{13} \mathrm{C}$-ppGpp internal standard during HPLC-MS/MS analysis. ppGpp concentrations were therefore calculated using the ${ }^{13} \mathrm{C}$-GTP internal standard adjusted for the response factor to estimate recovery. Fig. $\mathrm{S} 1$ shows absolute quantification of ppGpp based on the ${ }^{13} \mathrm{C}-\mathrm{ppG}$ pp internal standard.

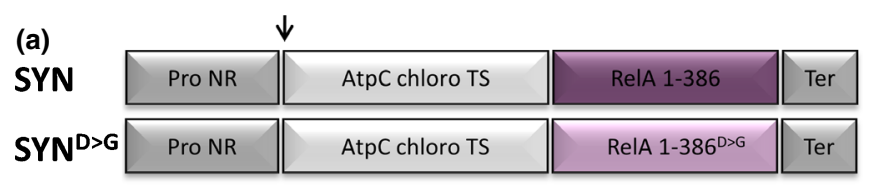

(b)
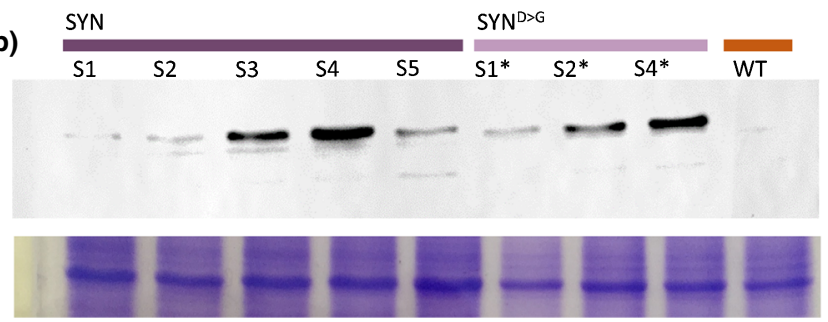

(c)

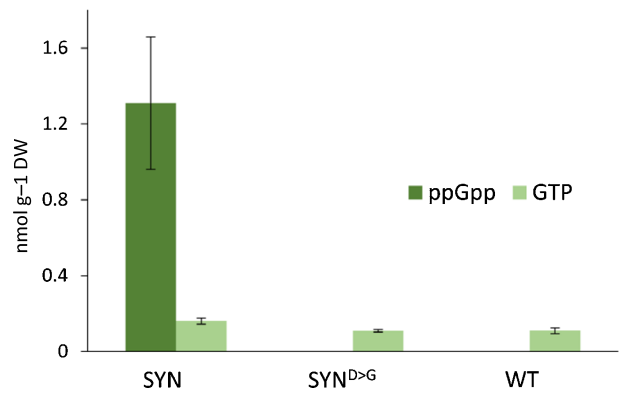

Fig. 1 The creation of nitrate-inducible lines for the accumulation of guanosine penta- and tetraphosphate (ppGpp) in

Phaeodactylum tricornutum. (a) Schematic representation of the construction used for the transformation of $P$. tricornutum cells. The nitrate reductase promoter (Pro NR) and terminator (Term) were from the pPha-NR vector. The bipartite targeting sequence was from the chloroplastic gamma ATP synthase (AtpC chloro TS). The genes encode a (p)ppGpp synthetase (SYN) and an inactive synthetase (SYN $\left.{ }^{\mathrm{D}>\mathrm{G}}\right)$. (b) Western blot analysis of extracts from independent SYN (S1-S5) and $\mathrm{SYN}{ }^{\mathrm{D}>\mathrm{G}}\left(\mathrm{S} 1^{*}-\mathrm{S} 4^{*}\right)$ transgenic lines and the wild-type (WT) grown in inducing $\mathrm{f} / 2-\mathrm{NO}_{3}$ media using anti-RelA antibodies specific for the RelA domain in SYN and SYN ${ }^{D>C}$. Each well was loaded with $7 \times 10^{4}$ cells. Coomassie blue staining is shown as a loading control. (c) At $2 \mathrm{~d}$ after transfer to inducing $\mathrm{f} / 2-\mathrm{NO}_{3}$ media, ppGpp and guanosine triphosphate (GTP) concentrations were determined in SYN $( \pm \mathrm{SE}, n=5$ independent lines), $\mathrm{SYN}^{\mathrm{D}>\mathrm{G}}$ ( $\pm \mathrm{SE}, n=4$ independent lines) and WT lines ( $\pm \mathrm{SE}, n=3$ independent replicates).

\section{Growth parameters and pigment quantification}

For the analysis of growth, phenotype cells were grown in $25 \mathrm{ml} \mathrm{liq-}$ uid $\mathrm{f} / 2-\mathrm{NH}_{4}$ in $250 \mathrm{ml}$ Erlenmeyer flasks, without agitation, in triplicate for five different transformants. Optical density (OD) at $750 \mathrm{~nm}$ and number of cells were monitored every $24 \mathrm{~h}$. Cell number showed a linear relationship with OD $750 \mathrm{~nm}$ up to an OD of 1. Cultures were inoculated from a preculture to an initial $\mathrm{OD}$ $750 \mathrm{~nm}$ of 0.05 . After $48 \mathrm{~h}$, cells were centrifuged at $5000 \mathrm{~g}$ (Allegra $^{\circledR} \mathrm{X}-15 \mathrm{R}$ Centrifuge; Beckman Coulter) for $10 \mathrm{~min}$ at $16^{\circ} \mathrm{C}$ and the medium was substituted with $\mathrm{f} / 2-\mathrm{NO}_{3}$ to induce the expression of $S Y N$ or $S Y N^{D>G}$. For control cultures, the medium was substituted with fresh $\mathrm{f} / 2-\mathrm{NH}_{4}$. Pigments were extracted on ice from cell pellets $\left(1.6 \times 10^{7}\right.$ cells) with $1 \mathrm{ml} 96 \%(\mathrm{v} / \mathrm{v})$ ethanol, maintained in the dark for $30 \mathrm{~min}$ and centrifuged at $13000 \mathrm{~g}$ for $10 \mathrm{~min}$ at $4^{\circ} \mathrm{C}$. The spectra of the supernatant from 350 to $750 \mathrm{~nm}$ were recorded using a PTP-6 Peltier System spectrophotometer (Perkin Elmer, Waltham, MA, USA). Chlorophyll $a$ and $c$ concentrations were calculated according to Ritchie (2006) and fucoxanthin concentration according to Wang et al. (2018). For extended darkness, at $24 \mathrm{~h}$ after induction cells were transferred to darkness for $21 \mathrm{~d}$.

\section{Light microscopy and cell measurement}

Light microscopy images of live cells were taken using a Motic BA410 microscope equipped with a Moticam 1080 camera (Motic, Barcelona, Spain). Images were used to determine the length and width of individual cells using the Motic Image 3 PLus software after calibration of the microscope. For fluorescence microscopy, cells were incubated with the fluorescent dye AC202 as described in Harchouni et al. (2018). Fluorescence was visualized in an epifluorescence microscope Eclipse 80i (Nikon) using the DAPI filter cube (excitation filter, 360BP40; emission filter, 460BP50). Images were acquired using MS ELEMENTS imaging software (Nikon, Melville, NY, USA). Images were merged using IMAGEJ software.

\section{Electron microscopy and immunogold labelling}

Procedures for electron microscopy and immunogold labelling are described in Methods S1.

\section{Measurement of photosynthetic activity}

Chlorophyll fluorescence parameters were measured using a Fluorcam FC 800-O imaging fluorometer (Photon System Instruments, Drasov, Czech Republic). Cells plated on solid medium were recovered in $\mathrm{f} 2 / \mathrm{NH}_{4}$ medium and $10 \mu \mathrm{l}$ of this cell suspension (between 5 and $9 \times 10^{7}$ cells ml ${ }^{-1}$ ) was dotted onto $\mathrm{f} 2 / \mathrm{NO}_{3}$ or $\mathrm{f} 2 / \mathrm{NH}_{4}$ medium and grown under standard growth conditions. Before measurement, the plates were kept in the dark for $20 \mathrm{~min}$ and the Chl fluorescence was imaged to obtain minimum $\left(F_{\mathrm{o}}\right)$ and maximum fluorescence yield $\left(F_{\mathrm{m}}\right)$. photosystem II (PSII) maximum efficiency was calculated as $F_{\mathrm{v}} / F_{\mathrm{m}}=\left(F_{\mathrm{m}}-F_{\mathrm{o}}\right) /$ $F_{\mathrm{m}}$. To calculate relative electron transfer rate $(\mathrm{rETR})$, samples were exposed to different photon flux densities (PPFD) in a 
stepwise fashion. Relative ETR was then calculated as the product of the photochemical yield of PSII $\left(\Phi \mathrm{P}=\Delta F / F_{\mathrm{m}}{ }^{\prime}=\left(F_{\mathrm{m}}{ }^{\prime}-F_{\mathrm{o}}\right) /\right.$ $\left.F_{\mathrm{m}}{ }^{\prime}\right)$ and PPFD.

\section{Cell extract, SDS-PAGE and immunoblotting}

Phaeodactylum tricornutum cells $\left(2 \times 10^{7}\right)$ were harvested from liquid culture by centrifugation $\left(5000 \mathrm{~g}\right.$ for $15 \mathrm{~min}$ at $\left.18^{\circ} \mathrm{C}\right)$ and resuspended in $100 \mu \mathrm{l}$ of rupture buffer $(10 \mathrm{mM}$ Tris, $\mathrm{pH} 8$ containing $2 \% \mathrm{n}$-dodecyl $\beta$-D-maltoside) and then broken by sonication using six pulses from an ultrasonicator (Sonics \& Materials Inc., Vibracell, Bioblock, Danbury, CT, USA). After incubation at $4^{\circ} \mathrm{C}$ for $30 \mathrm{~min}$, the cell extract was centrifuged at $12000 \mathrm{~g}$ for $30 \mathrm{~min}$ at $4^{\circ} \mathrm{C}$. The supernatant was submitted to sodium dodecyl sulphate-polyacrylamide gel electrophoresis (SDS-PAGE) and gels were stained with Coomassie blue R-250. For Western blot analysis, proteins were transferred onto nitrocellulose membrane as previously described (Sambrook et al., 1989). Loading control gels were run in parallel. The membrane was blocked with TBS (Tris $10 \mathrm{mM}, \mathrm{pH} 8,150 \mathrm{mM} \mathrm{NaCl}$ ) containing 5\% nonfat milk and incubated with the specified primary antibodies in the same buffer containing $1 \%$ nonfat milk. The antibodies used were as follows: anti-E.coli RelA (dilution 1:2000, kindly provided by M. Cashel), anti-haemagglutinin (HA) (monoclonal, dilution 1:10000; H9658, clone HA-7; Sigma-Aldrich), antiPsbA (polyclonal, dilution 1:10 000; AS05 084; Agrisera) and anti-P. tricornutum LHCf1-LHCf11 (Juhas and Buchel, 2012) (polyclonal, dilution $1: 5000$, kindly provided by C. Büchel). After washing with TBS, the membranes were incubated with either horseradish peroxidase;coupled anti-rabbit IgG (NA934V; GE Healthcare, Pittsburg, PA, USA) for the polyclonal antibodies or anti-mouse IgG (Sigma-Aldrich) for the monoclonal antibodies. Immunodetection was performed using the enhanced chemiluminescence method (ECL substrates, GE Healthcare).

\section{Lipid and chrysolaminarin determination}

The fluorescent probe Nile red was used to detect neutral lipids by flow cytometry as specified in Prioretti et al. (2017). The cells at different growth phases were fixed with $2 \%(\mathrm{v} / \mathrm{v})$ glutaraldehyde (Prioretti et al., 2017) and $1 \mathrm{ml}$ of cell suspension was incubated with $2 \mu \mathrm{l}$ of Nile red solution $\left(0.25 \mathrm{mg} \mathrm{m}^{-1}\right)$ for $5 \mathrm{~min}$ before the analysis with a bench flow cytometer (BD Accuri C6; BD Biosciences, San Jose, CA, USA). To determine Nile red fluorescence, the trigger signal was set to FL2 fluorescence and combined with the side scatter signal. Ten thousand events were analysed in each case.

For lipid analysis, cells of $P$. tricornutum $\left(50 \times 10^{6}\right.$ cells $)$ were harvested by centrifugation $\left(5000 \mathrm{~g}\right.$, for $10 \mathrm{~min}$ at $\left.4^{\circ} \mathrm{C}\right)$ and the pellet was resuspended with $1 \mathrm{ml}$ of hot isopropanol (preheated at $85^{\circ} \mathrm{C}$ ) and incubated at this temperature for $10 \mathrm{~min}$ to quench endogenous lipases. Detailed lipid extraction protocol can be found in Legeret et al. (2016). Extracted total lipids were then dried under a stream of $\mathrm{N}_{2}$ and then dissolved in a solvent mixture of chloroform: methanol $(2: 1, \mathrm{v} / \mathrm{v})$ for quantification by thin layer chromatography (TLC). Two types of TLC were run: one for triacylglycerol (TAG) quantification, and a second for polar membrane lipid analysis. Detailed TLC procedures, standard used and quantifications have been described, together with total fatty acid (FA) content and composition analysis in Siaut et al. (2011).

Extraction and determination of the $\beta$-1,3-glucan chrysolaminarin were performed following the method of Granum \& Myklestad (2002) from pellets containing $2 \times 10^{7}$ cells. A calibration curve was obtained using glucose as a standard.

\section{Mass spectrometry analysis}

Protein extracts $(50 \mu \mathrm{g}$ protein) from three SYN lines, two $S Y N^{D>G}$ lines and one $\mathrm{WT}$, on equal numbers of cells, were loaded onto a gel (SDS-PAGE) and the band from the stacking gel corresponding to the total proteins was excised and submitted to in-gel trypsin digestion for proteomic analysis as previously described (Santin et al., 2018), with minor modifications. In parallel, total proteins were also separated to analyse the protein profile in the gel (Fig. S2). Tryptic peptide samples were quantified by a colorimetric peptide assay (Pierce, Thermo Fisher Scientific, Waltham, MA, USA) and aliquots of $200 \mathrm{ng}$ were injected by LC-MS/MS. Two LC-MS/MS injections were performed per condition (technical replicates). Spectral data were processed for protein identification and quantification using the MaxQuant computational proteomics platform (v.1.6.5.0) integrating the search engine Andromeda and the MAxLFQ algorithm (Cox et al., 2014). The results are illustrated in a volcano plot (Fig. S3), and the list of identified proteins and differentially accumulating proteins in SYN vs the control lines is available in Table S2. Full details of LC-MS/MS analysis conditions and quantification are provided in Methods S1.

\section{Results}

\section{An inducible (p)ppGpp synthetase efficiently increases ppGpp concentrations in $P$. tricornutum}

As a first step towards understanding the function of (p)ppGpp in diatoms, we developed a strategy similar to that reported in Arabidopsis (Sugliani et al., 2016), where (p)ppGpp accumulation was triggered using a constitutively active fragment of a bacterial (p)ppGpp synthetase. For this purpose, we transformed P. tricornutum with a chimeric gene (SYN) encoding the chloroplast targeting peptide of the chloroplastic gamma ATP synthetase (Apt et al., 2002; Liu et al., 2016) and a constitutively active fragment of the (p)ppGpp synthetase RelA (Schreiber et al., 1991) (Fig. 1a). SYN was placed under the control of an $\mathrm{NO}_{3}$-inducible promoter. Control transgenic lines were also generated that express catalytically inactive forms of the same enzyme, $S Y N^{D>G}$. Multiple independent positive transformants were identified by PCR and analysed to confirm protein expression following induction by transfer from $\mathrm{NH}_{4}$-containing medium to $\mathrm{NO}_{3}$-containing medium (Fig. 1b). We confirmed that the SYN protein was targeted to the chloroplast by immunogold labelling (Fig. S4). 
Importantly, induction of SYN lines also caused an increase in ppGpp concentrations from below the limits of detection to $1.30 \pm 0.34 \mathrm{nmol} \mathrm{mg}^{-1}$ dry cell weight $(n=5$ independent biological replicates) (Fig. 1c). pppGpp was not detected, suggesting that SYN preferentially acts as a ppGpp synthetase, and/or that pppGpp can be converted to ppGpp by endogenous enzymes as in bacteria. No ppGpp was detected in $S Y N^{D>G}$ lines or the wildtype (WT) under inducing conditions. The absence of basal concentrations of ppGpp is likely to be a consequence of the nutrient shift used for induction because we were able to detect low quantities of ppGpp in WT cells grown in standard media in the light (Fig. S1). Interestingly, we also observed that incubation of cells in the dark for prolonged periods led to the accumulation of ppGpp. We simultaneously quantified GTP concentrations and found that they were similar to the WT control regardless of ppGpp concentrations (Figs 1c, S1).
ppGpp accumulation strongly inhibits cell division and has a major effect on photosynthesis

We first examined the effects of ppGpp accumulation on growth and proliferation. Five independent SYN lines showed a severe reduction in proliferation upon induction in liquid culture (Figs 2a, S5). By contrast, induction did not affect the proliferation of control SYN ${ }^{\mathrm{D}>\mathrm{G}}$ lines or the WT. The reduced proliferation of SYN lines was also clearly visible on agar plates following induction (Fig. 2b). Observation by light microscopy showed that proliferation continued slowly up to at least $9 \mathrm{~d}$ after induction, with no cell death or damage visible by microscopic observation (Table S3). We also found that SYN cells were significantly longer than those of the controls while maintaining the same width (Fig. 2c). The elongated phenotype of SYN cells may be linked to the reduction in division rate (Fig. 2c).
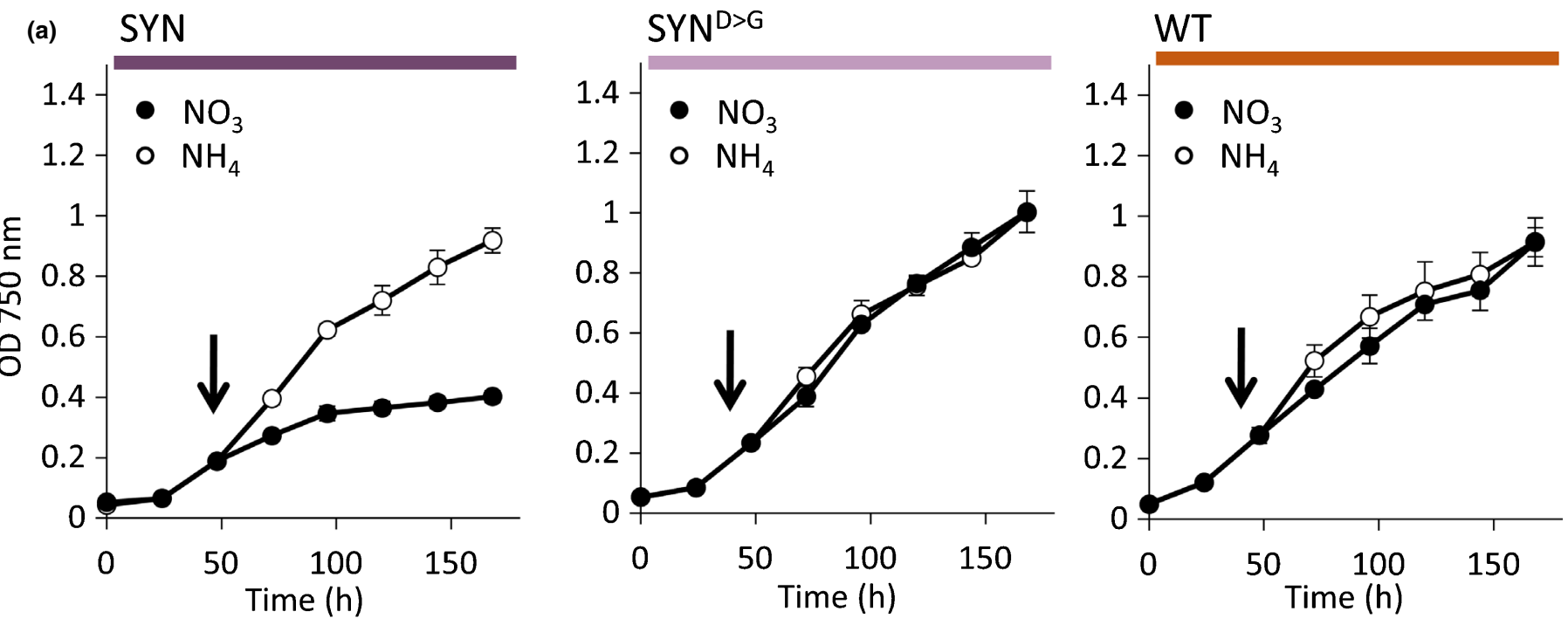

(b) $\mathrm{NH}_{4}$
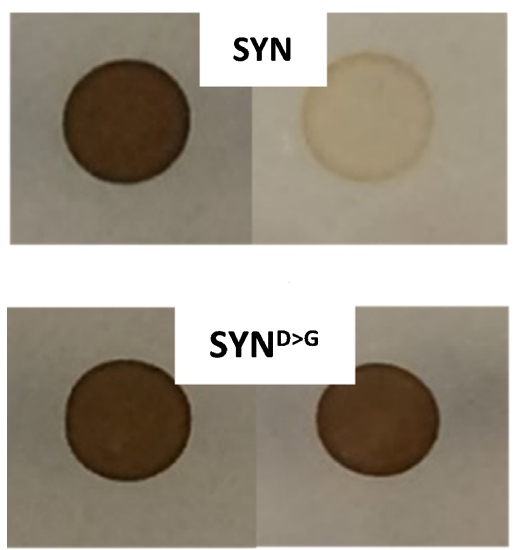

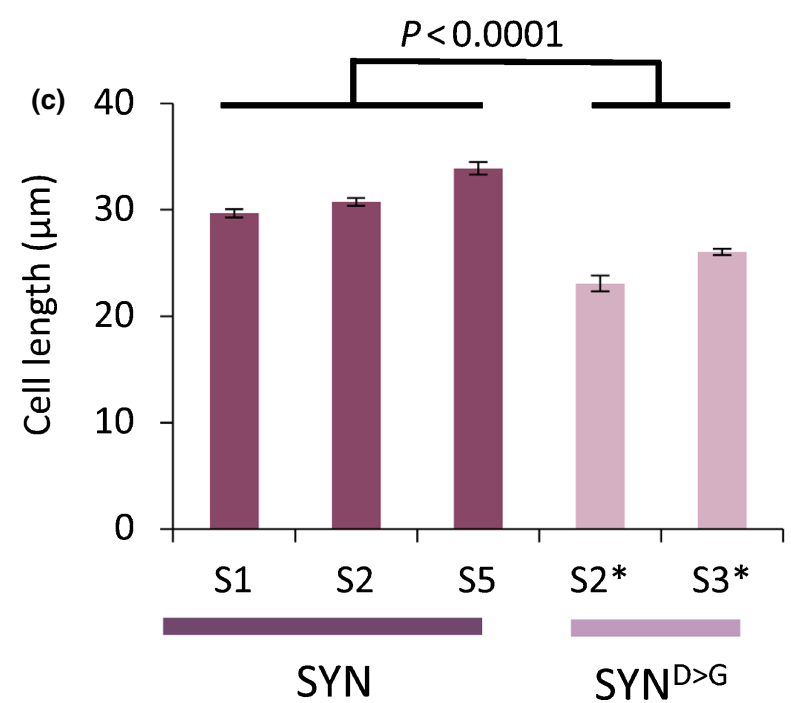

Fig. 2 Guanosine penta- and tetraphosphate (ppGpp) accumulation affects proliferation and cell elongation. (a) Growth curves of synthetase (SYN), inactive synthetase $\left(\mathrm{SYN}^{\mathrm{D}>\mathrm{G}}\right.$ ) and wild-type (WT) Phaeodacty/um tricornutum lines. Cells grown inf/2- $\mathrm{NH}_{4}$ were transferred (arrow) to either $\mathrm{f} / 2-\mathrm{NO} \mathrm{O}_{3}$ $\left(\mathrm{NO}_{3}\right)$ for induction or $\mathrm{f} / 2-\mathrm{NH}_{4}\left(\mathrm{NH}_{4}\right)$ as controls. Data are means $\pm \mathrm{SE}$ of three biological replicates. (b) Cells $\left(S Y N\right.$, $\left.S Y N^{\mathrm{D}>\mathrm{G}}\right)$ initially grown in liquid $\mathrm{f} / 2$ $\mathrm{NH}_{4}$ were grown as cell colonies on agar plates in the presence of either $\mathrm{NO}_{3}$ or $\mathrm{NH}_{4}$ as controls. (c) Cell length for independent $S Y N$ and $S Y N{ }^{\mathrm{D}>\mathrm{C}}$ lines at $5 \mathrm{~d}$ post-induction ( $\pm \mathrm{SE}, n$ between 60 and 194 cells). No difference in cell width was observed $(P=0.059)$. Statistical significance was calculated using ANOVA with post hoc Dunnett test. 

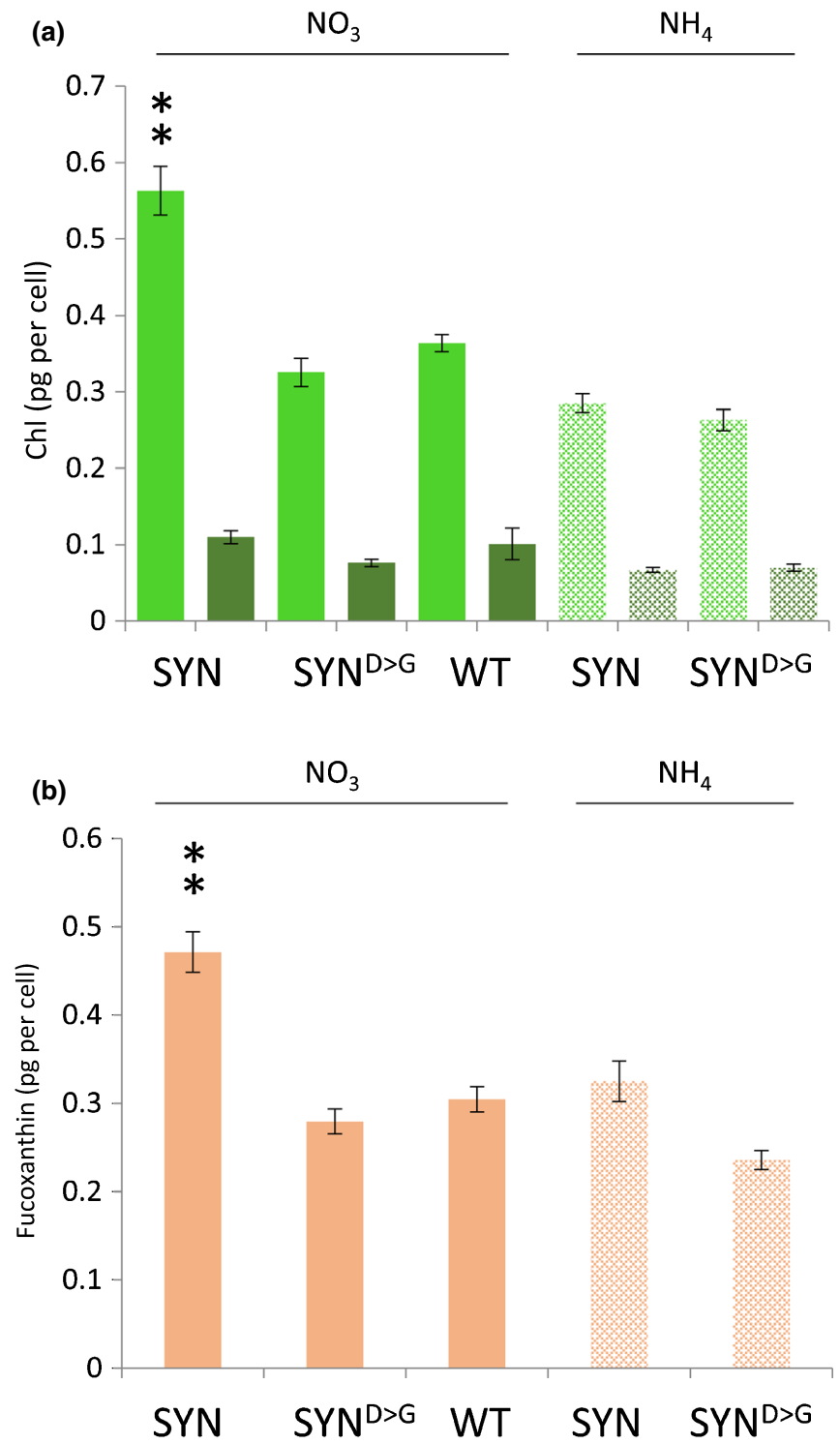

Fig. 3 Pigment concentrations are maintained in induced synthetase (SYN) lines. Different Phaeodacty/um tricornutum lines grown in $\mathrm{f} / 2-\mathrm{NH}_{4}$ were transferred to inducingf/2- $\mathrm{NO}_{3}$ media $\left(\mathrm{NO}_{3}\right)$ or noninducing $\mathrm{f} / 2-\mathrm{NH} 4$ media $\left(\mathrm{NH}_{4}\right)$. Pigments were extracted at $5 \mathrm{~d}$ post-induction, corresponding to the stationary phase of the growth curve, and the concentrations of Chla (light green) and Chlc (dark green) (a) and fucoxanthin (b) were determined. Data are means \pm SE of five biological replicates. Statistical significance was calculated using ANOVA with post hoc Dunnett tests vs wild-type (WT) control: **, $P<0.01$.

We then analysed pigment content at different times after induction (Figs 3, S6). In the WT, the concentrations of Chla and fucoxanthin decrease as the cells enter the stationary phase, at $5 \mathrm{~d}$ post-induction. To our surprise, we found that this drop in pigment content does not occur in induced SYN lines: at $5 \mathrm{~d}$ after induction, concentrations of Chla and fucoxanthin are significantly higher in SYN than in SYN ${ }^{\mathrm{D}>\mathrm{G}}$ or the WT (Fig. 3). By contrast, the drop in Chlc concentrations was similar in all lines, leading to a higher Chla: Chlc ratio in the SYN lines (Fig. 3). These results suggest that ppGpp accumulation inhibits cell division while stabilizing Chl $a$ and fucoxanthin concentrations in the chloroplast.

In Arabidopsis, ppGpp accumulation has major effects on photosynthetic activity (Maekawa et al., 2015; Sugliani et al., 2016). We therefore examined the maximal efficiency of PSII $\left(F_{\mathrm{v}} / F_{\mathrm{m}}\right)$ (Fig. $\left.4 \mathrm{a}-\mathrm{c}\right) . F_{\mathrm{v}} / F_{\mathrm{m}}$ decreased rapidly in induced SYN transformants following induction, reaching a minimum $( \pm \mathrm{SE})$ of $0.12 \pm 0.004$ at $2 \mathrm{~d}$ post-induction (Figs $4 \mathrm{a}, \mathrm{b}, \mathrm{S} 7$ ). The decrease in $F_{\mathrm{v}} / F_{\mathrm{m}}$ was a result of an increase in basal fluorescence (Fo). By contrast, the $F_{\mathrm{v}} / F_{\mathrm{m}}$ of the control SYN ${ }^{\mathrm{D}>\mathrm{G}}$ lines was 0.6 at the same time point after induction. We performed immunoblots to determine whether the decrease in $F_{\mathrm{v}} / F_{\mathrm{m}}$ in induced SYN lines was a result of changes in PSII architecture. Indeed, we found that the amounts of the chloroplast-encoded protein D1, a subunit of the PSII reaction centre, decreased in SYN lines (Fig. 4d). By contrast, the total abundances of the light-harvesting proteins LHCf1-11, which form a major part of the FCP antenna, remained relatively constant (Fig. 4d). These results indicate that the composition of PSII undergoes major changes in response to ppGpp accumulation. In line with the reduced PSII efficiency, the rETR of the entire photosynthetic chain was also lower in SYN lines than in the WT or $S Y N^{D>G}$ controls (Fig. 4e,f).

\section{ppGpp affects the accumulation and distribution of lipids and other reserve compounds}

Using light microscopy, we observed a prominent spot near, but clearly separated from, the chloroplast in all SYN lines at $2 \mathrm{~d}$ post-induction (Fig. 5a). This spot was absent in noninduced SYN (Fig. 5b) and was not detected in $S Y N^{\mathrm{D}>\mathrm{G}}$ lines regardless of the condition (Fig. $5 \mathrm{c}$,d). The prominent spot that was clearly visible under light microscopy was strongly stained by the neutral lipid-specific fluorophore AC202, indicating that it is a lipid droplet (LD) (Fig. 5e). Observation of the LD by electron microscopy indicated a probable localization within the periplastidial compartment (Fig. S8). AC202 staining revealed the presence of small chloroplast-associated LDs in the control SYN ${ }^{\mathrm{D}>\mathrm{G}}$ line (Fig. 5f) and the WT. These droplets differ in size and location from the prominent cytoplasmic LD observed in induced SYN lines and are not visible by light microscopy. The prominent LD in SYN cells disappeared at $5 \mathrm{~d}$ after induction (Fig. $5 \mathrm{~g}$ ). This corresponds to the stationary phase of the growth curve, when numerous $\mathrm{LDs}$ appear in $\mathrm{SYN} \mathrm{N}^{\mathrm{D}>\mathrm{G}}$ and the WT (Figs 5h, S9). LDs are indeed well known to accumulate in diatoms with the ageing of the culture (Hu et al., 2008).

To further characterize the prominent LD in SYN cells, we analysed neutral lipid content at different stages of the growth using flow cytometry and Nile red staining and then confirmed by quantification using TLC (Fig. 6a). A strong correlation between Nile red fluorescence and TAG content is established in diatoms (Greenspan et al., 1985; Prioretti et al., 2017). Nile red fluorescence, determined using flow cytometry, increased with the age of the culture in WT and SYN ${ }^{\mathrm{D}>\mathrm{G}}$ cells, but not in SYN cells, in agreement with our microscopic observations (Fig. $5 \mathrm{~g}, \mathrm{~h}$ ). However, flow cytometry was not sensitive enough to detect 
Fig. 4 Guanosine penta- and tetraphosphate (ppGpp) accumulation downregulates photosynthetic activity in

Phaeodactylum tricornutum. (a) The maximal efficiency of photosystem II $\left(F_{\mathrm{v}} / F_{\mathrm{m}}\right)$ was measured on dark-adapted cells of independent synthetase (SYN), inactive synthetase ( $S Y N^{D>G}$ ) and wild-type (WT) $P$. tricornutum lines at $2 \mathrm{~d}$ post-induction. Data are means $\pm \mathrm{SE} ; n=7$ colony spots per line. (b) Average $F_{\mathrm{v}} / F_{\mathrm{m}}$ of grouped lines for SYN, SYN ${ }^{\mathrm{D}>\mathrm{G}}$ and WT shown in (a).

Statistical significance was calculated using ANOVA with post hoc Dunnett tests vs WT control: **, $P<0.01$. (c) $F_{\mathrm{v}} / F_{\mathrm{m}}$ false colour image of cell colonies of SYN, SYN ${ }^{D>C}$ and WT at $1 \mathrm{~d}$ post-induction. (d) Immunoblots of protein extracts from equal numbers of cells $\left(7 \times 10^{4}\right)$ at $2 \mathrm{~d}$ post-induction using primary antibodies against D1 and LHCf111. $(e, f)$ Relative electron transfer rate ( $r E T R)$ at different light intensities in uninduced (e) and induced (f) SYN, SYN ${ }^{D>C}$ and WT $P$. tricornutum lines at $2 \mathrm{~d}$ postinduction. Data are means \pm SE for data from grouped lines (five $S Y N$ lines, four $S Y N^{D>G}$ lines).
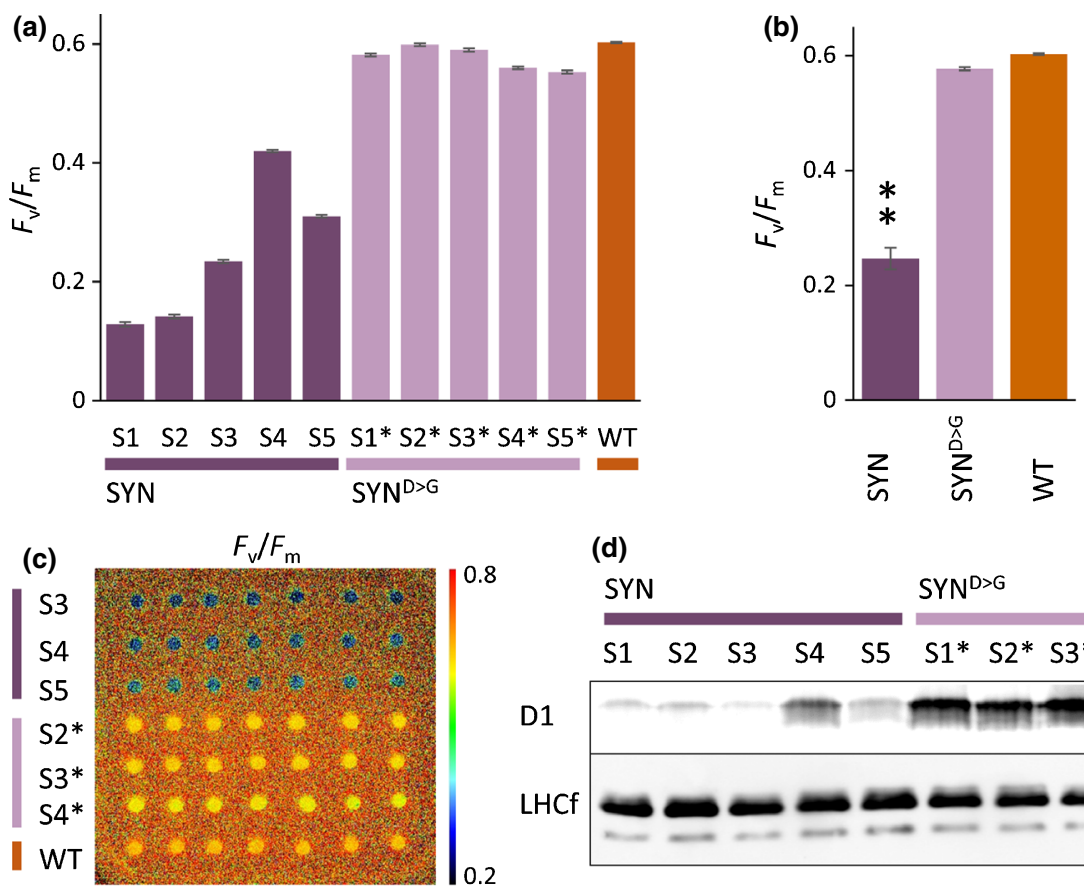

(d)

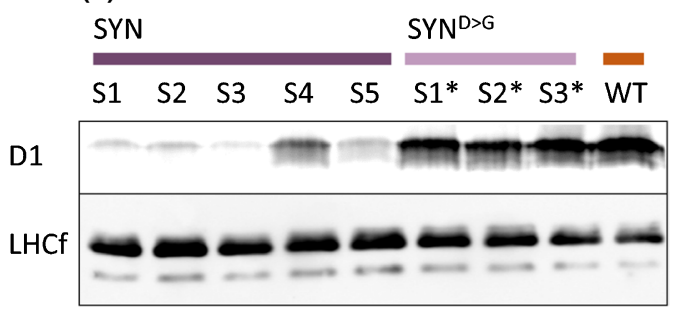

(e)

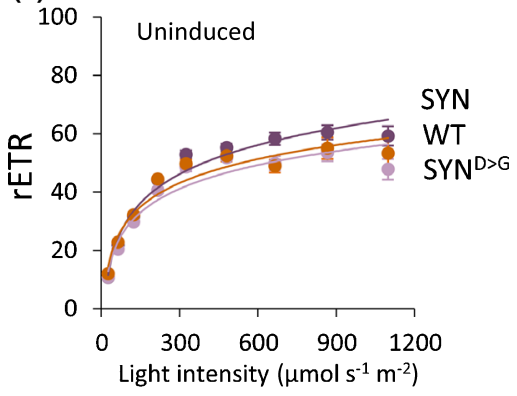

differences in lipid content at $2 \mathrm{~d}$ post-induction. Therefore, we directly quantified TAG by extraction of total lipids followed by TLC quantification (Fig. 6b,c). At $2 \mathrm{~d}$ post-induction, the amount of TAG per cell was almost two-fold higher in the SYN lines than in the controls $(P=0.213)$ (Fig. 6b). Although not significant, this finding tends to support our microscopic observation of higher neutral lipid concentrations in SYN lines at $2 \mathrm{~d}$ after induction (Fig. 5a). However, at $5 \mathrm{~d}$ post-induction, SYN lines contained much lower (six-fold) concentrations of neutral lipids than the control lines, in agreement with the flow cytometry results (Fig. 6c) and microscopy images (Fig. 5g,h). Chrysolaminarin ( $\beta$-1,3-glucan), the main carbohydrate storage compound in diatoms, which is located in the vacuole (Suzuki \& Suzuki, 2013), was also less abundant in induced SYN lines than in the controls at $5 \mathrm{~d}$ post-induction (Fig. S10).

To investigate the impact of altered ppGpp concentrations on membrane lipids, we also analysed polar lipid content. In the membranes of the diatom chloroplast, as in the chloroplasts of other photosynthetic organisms, polar lipids are essentially composed of monogalactosyldiacylglycerol (MGDG), digalactosyldiacylglycerol (DGDG), sulfoquinovosyldiacylglycerol (SQDG) and phosphatidylglycerol (PG) (Abida et al. 2015). Polar lipids in SYN cells at $2 \mathrm{~d}$ after induction did not significantly differ from those of WT or SYN ${ }^{\mathrm{D}>\mathrm{G}}$ controls (Fig. S11). However, at $5 \mathrm{~d}$ after induction, with the exception of DGDG and PG, the concentration of all the other polar lipids (MGDG, SQDG, phosphatidylcholine (PC), phosphatidylethanolamine (PE), phosphatidylserine (PS)) remained higher in SYN cells than in the SYN ${ }^{\mathrm{D}-\mathrm{G}}$ and WT controls (Fig. 7a). Furthermore, FA content and composition in SYN cells were different from the controls at $5 \mathrm{~d}$ after induction, with substantially lower concentrations of the most abundant FAs (16:0 and $16: 1$ ), and decreases in $18: 1$ and $18: 2$. These changes are consistent with the lower TAG concentrations in SYN lines, because $16: 0,16$ : $1,18: 1$ and $18: 2$ are the main FA species found in TAG under nutrient-limiting conditions in P.tricornutum (Abida et al., 2015).

Proteome analysis reveals that ppGpp accumulation leads to the coordinated upregulation of the protein protection response

The analysis of the protein profiles of induced SYN, SYN ${ }^{\mathrm{D}>\mathrm{G}}$ and WT by SDS-PAGE revealed major changes in total proteins 

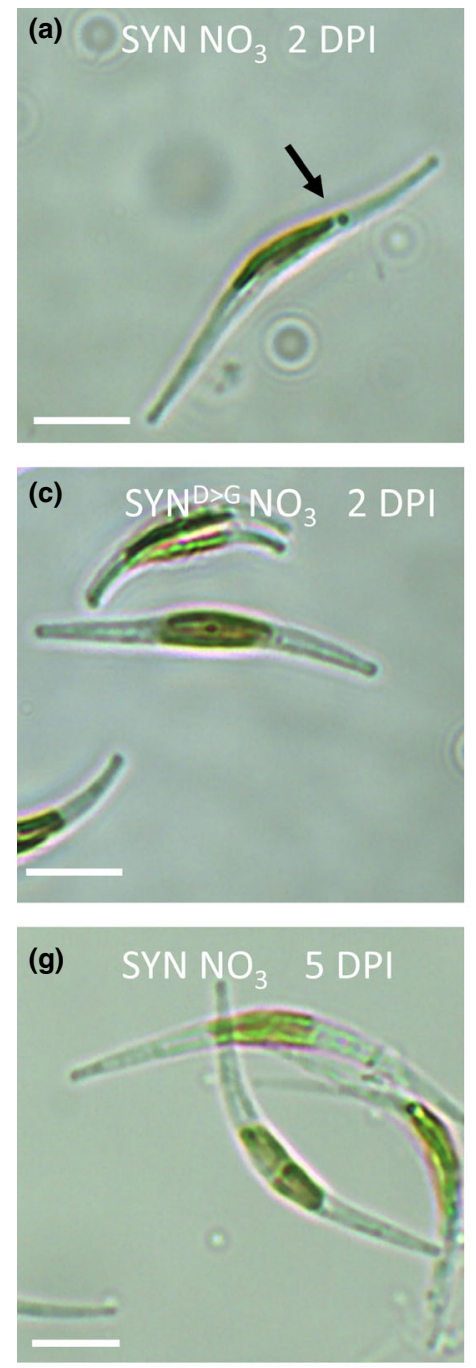
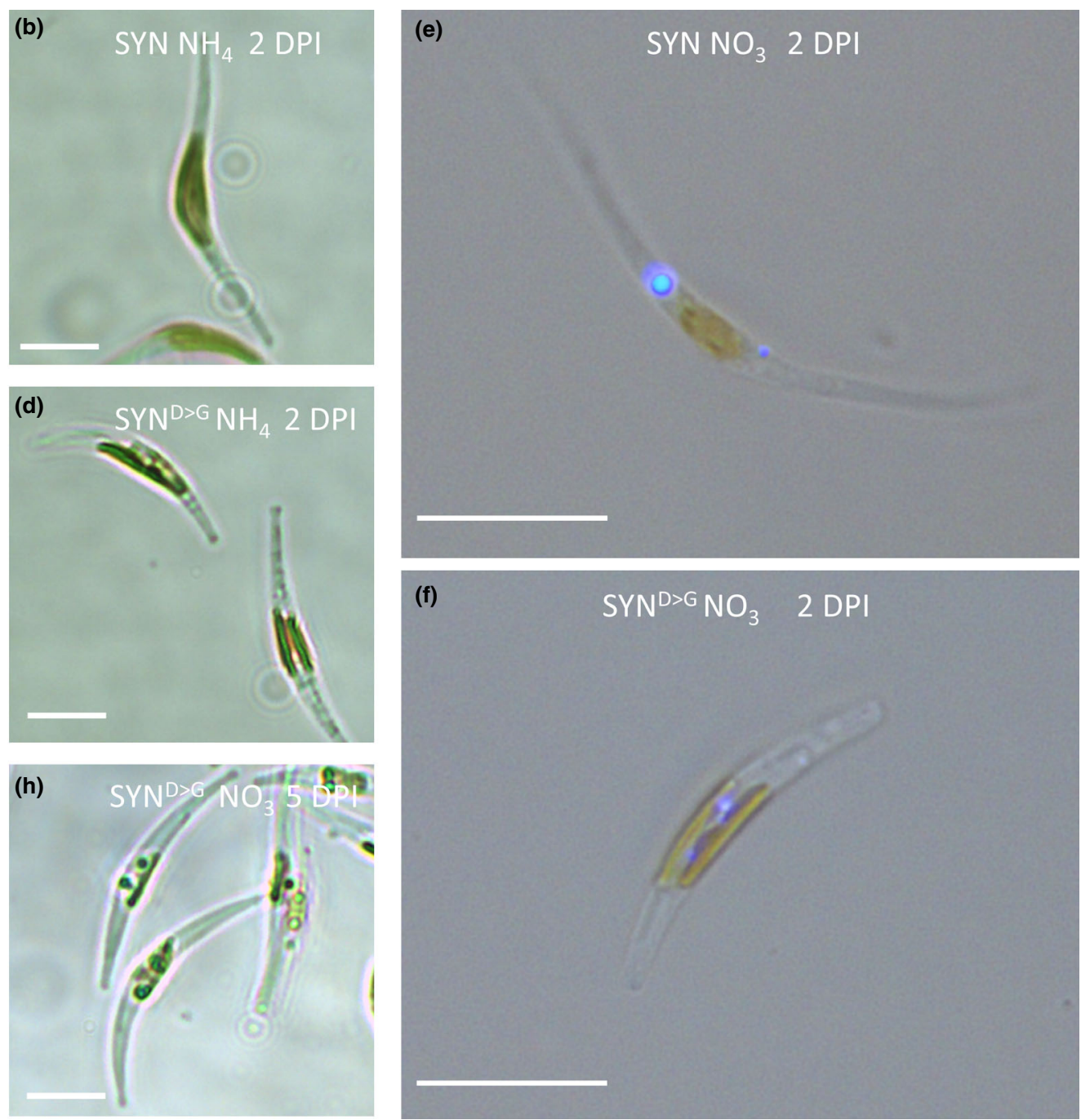

Fig. 5 Guanosine penta- and tetraphosphate (ppGpp) accumulation affects lipid droplet formation in Phaeodactylum tricornutum. (a, b) Induced (a) and noninduced (b) synthetase (SYN) cells after at 2 d post-induction (2 DPI). (c, d) Induced (c) and noninduced (d) SYN ${ }^{\mathrm{D}>\mathrm{G}}$ (an inactive mutant form of SYN) cells at $2 \mathrm{~d}$ post-induction. (e, f) Fluorescence microscopy images of SYN (e) and SYN ${ }^{\mathrm{D}>\mathrm{G}}$ ( $\mathrm{f}$ ) cells at $2 \mathrm{~d}$ post-induction (2 DPI) labelled with the neutral lipid-specific fluorophore AC202. (g, h) SYN (g) and SYN ${ }^{\mathrm{D}>\mathrm{G}}$ cells $(\mathrm{h})$ at $5 \mathrm{~d}$ after induction (5 DPI). Images are representative of multiple images and at least two independent experimental replicates. Bars, $10 \mu \mathrm{m}$.

in SYN lines, including the appearance of additional protein bands (Fig. S2). In order to understand the extent of these changes, we performed an untargeted proteomic analysis to compare protein accumulation between induced SYN lines and induced $S Y N^{\mathrm{D}>\mathrm{G}}$ lines at $2 \mathrm{~d}$ after induction. Of the 1046 proteins that were identified, 145 proteins showed a significant difference in accumulation in SYN compared with the control lines (Table S2). The expression of known housekeeping proteins (Siaut et al., 2007) was not affected by ppGpp accumulation, with the exception of actin 12 (Table S2). The major groups of proteins showing differential accumulation in SYN are listed in Table 1. Unexpectedly, many chaperones and co-chaperones showed higher levels of expression in SYN, and the chaperone heat shock protein 20 (HSP20; accession number B7G195) showed the greatest increase. The differentially expressed chaperones in SYN are encoded by nuclear genes and have different predicted cellular localizations. Four chaperones, including HSP40 and one isoform of HSP90, contain the ASAFAP hexapeptide motif that predicts likely chloroplast localization (Gruber et al., 2015). Other chaperones have signal peptides for the secretory pathway without an ASAFAP motif, suggesting localization in the endoplasmic reticulum. Some chaperones, such as the Lon protease, which functions as both a chaperone and a protease, are predicted to be mitochondrial.

We found that many transporters and enzymes involved in amino acid metabolism were among those proteins showing the greatest differential accumulation in the SYN lines (Table 1). Notably, the synthesis of glutamate appeared to be upregulated as a result of greater accumulation of the chloroplastic glutamate synthase and glutamate dehydrogenase, and lower concentrations of glutamine synthase. Glutamate is involved in nitrogen assimilation and is also a precursor for Chl biosynthesis. Interestingly, the chloroplast protoporphyrin IX magnesium chelatase, a key enzyme of the Chl biosynthetic pathway, was also more 


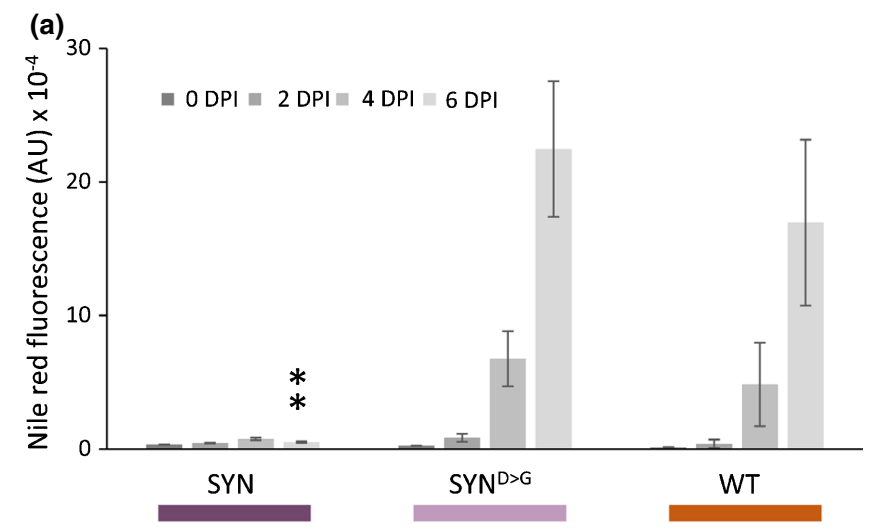

(b)
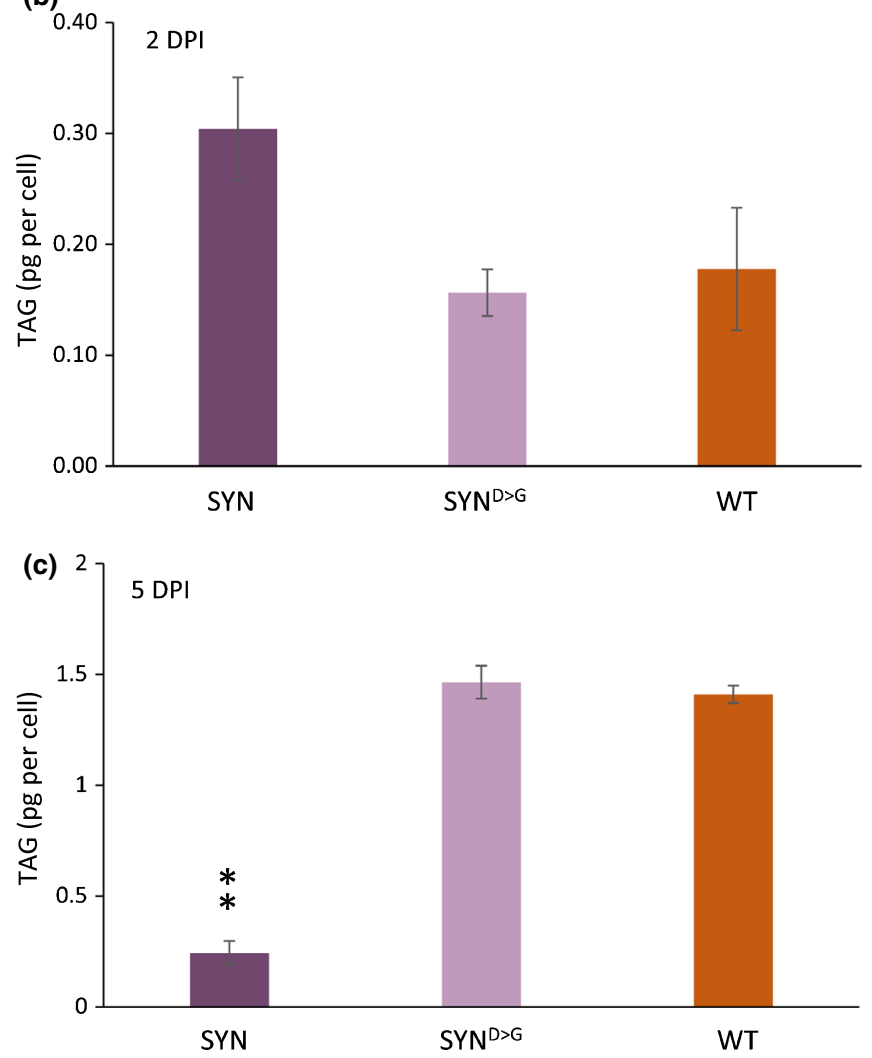

Fig. 6 Guanosine penta- and tetraphosphate (ppGpp) accumulation inhibits neutral lipid accumulation in the stationary phase. (a) Neutral lipid estimation by Nile red fluorescence in synthetase (SYN), inactive synthetase ( $\mathrm{SYN}^{\mathrm{D}>\mathrm{G}}$ ) and wild-type (WT) Phaeodactylum tricornutum lines at 0, 2, 4 and $6 \mathrm{~d}$ post-induction (DPI). Data are means $\pm \mathrm{SE}$ of three biological replicates. (b, c) Triacylglycerol (TAG) determination by thin layer chromatography (TLC) at $2 \mathrm{~d}$ post-induction (2 DPI) (b) and 5 DPI (c). Data are means \pm SE of five biological replicates. Statistical significance was calculated using ANOVA with post hoc Dunnett tests vs WT control: $* *, P<0.01$

abundant. Proteins of lipid metabolism were also affected. The concentrations of two enzymes involved in FA degradation increased: the mitochondrial acyl-CoA dehydrogenase (Jallet et al., 2020) and a homologue of enoyl-CoA hydratase, a key enzyme of FA beta-oxidation. Phage shock protein A, a protein that is involved in managing extra-cytoplasmic stress responses in bacteria (Joly et al., 2010), and glutathione S-transferase, an enzyme important in the redox homeostasis of the cell, were also more abundant.

Many chloroplast-encoded proteins with links to photosynthesis and chloroplast translation were less abundant in SYN. Seven proteins from the PSII complex accumulated to lower levels, including the PsbA/D1 protein, in agreement with our immunoblotting experiments (Fig. 4d). Some proteins from PSI and the Calvin cycle were also less abundant, as well as a bicarbonate transporter and two carbonic anhydrase proteins that were just outside the selection cut-off (Table S1), together indicating that photosynthetic capacity is diminished at several different levels. The photosynthetic machinery requires large amounts of iron, and consistent with the downregulation of photosynthesis we also observed the downregulation of two iron starvation-induced proteins. Interestingly, two light-harvesting antenna proteins, Lhcf15 and Lhcx2, were also less abundant. Therefore, although our immunoblotting experiment showed that total abundances of Lhcf1-11 remained unchanged (Fig. 4d), SYN induction also appears to cause changes in the accumulation of specific antenna isoforms. Also striking was the reduced abundances of 12 chloroplast-encoded ribosomal proteins in SYN cells, suggesting that ppGpp accumulation has a major effect on chloroplast translation capacity. The ribulose-1,5-bisphosphate carboxylase/oxygenase (Rubisco) remained unaltered in our proteomic analysis, as was also directly visible on Coomassie stained protein gels (Fig. S2).

\section{Discussion}

In the present work, we studied the function of (p)ppGpp using transgenic $P$. tricornutum SYN lines containing an inducible system for the expression of a bacterial (p)ppGpp synthetase (Fig. 1a). We demonstrate that increased ppGpp concentrations in SYN lines alter the architecture of the photosynthetic machinery and reduce photosynthetic efficiency (Fig. 4). In addition, ppGpp accumulation dramatically decreases the growth rate (Fig. 2), stabilizes the concentration of $\mathrm{Chl}$ and fucoxanthin (Fig. 4), and affects accumulation of the reserve molecules TAG and chrysolaminarin (Figs 5-7, S10, S11). Finally, ppGpp accumulation causes a striking increase in the abundances of chaperones and other stress-related proteins in multiple cellular compartments (Table 1; Fig. 8).

The independent SYN lines produced different quantities of SYN (Fig. 1). The differences we observed in SYN protein accumulation are probably a result of differences in the copy number or the insertion site(s) of the exogenous DNA in the independent transformants, as previously shown (Falciatore et al., 1999). Immunolabelling experiments showed that SYN accumulates preferentially in the chloroplast, further confirming the robust nature of the chloroplast targeting sequence used (Apt et al., 2002; Liu et al., 2016). Also in support of a principally chloroplastic localization for $S Y N$ is the presence of a single band in the immunoblots for SYN, indicating complete processing of the pre-protein (Fig. 1b), and the strong and specific effects that we observe on chloroplast gene expression that are discussed in more detail later in this section. The average concentrations of ppGpp 

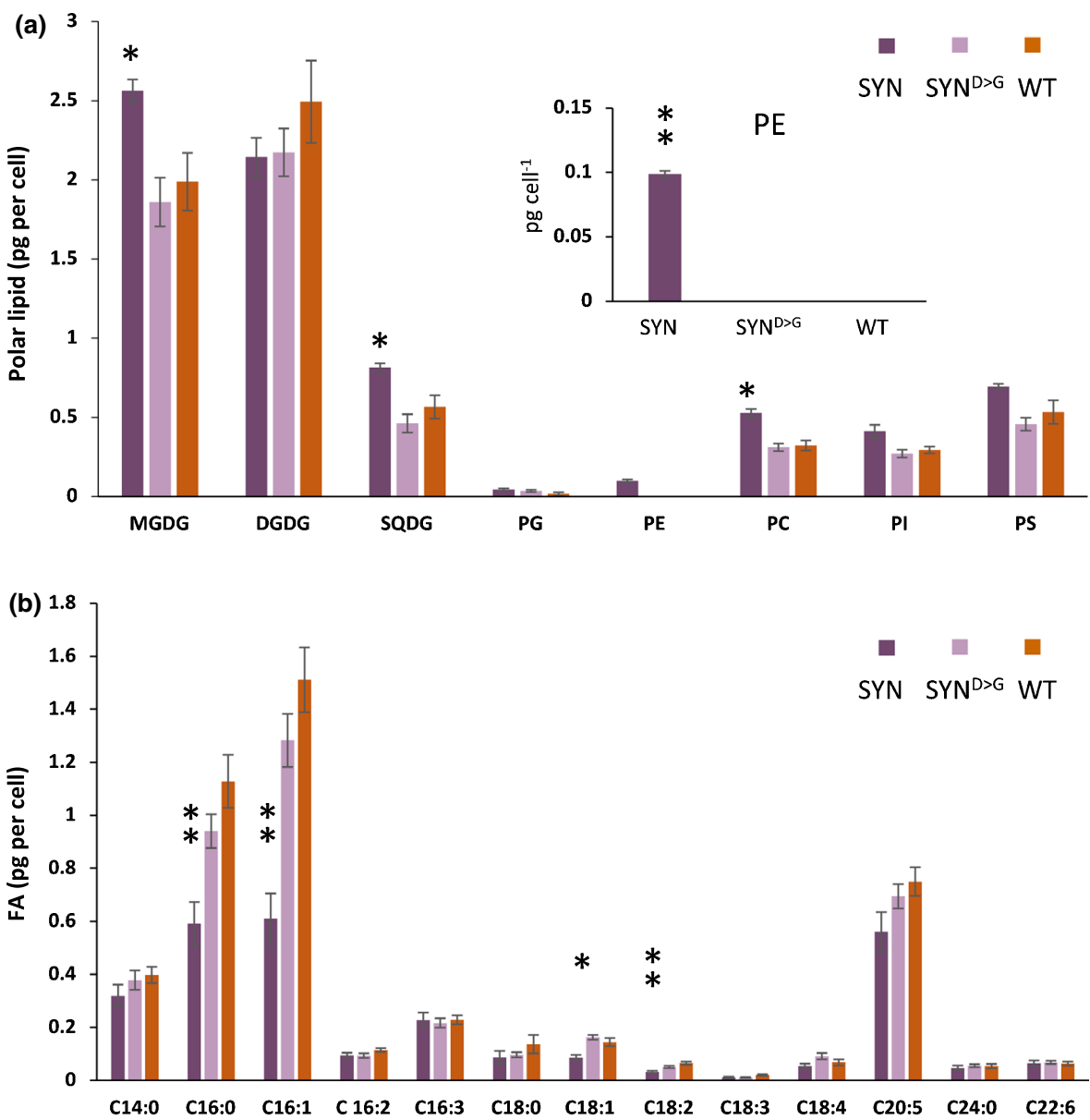

Fig. 7 Effects of guanosine penta- and tetraphosphate (ppGpp) on polar lipid and fatty acid composition. (a, b) Polar lipid (a) and fatty acid content (b) were determined in synthetase (SYN), inactive synthetase $\left(S Y N^{D>G}\right.$ ) and wild-type (WT)

Phaeodactylum tricornutum lines at $5 \mathrm{~d}$ postinduction. MGDG,

monogalactosyldiacylglycerol; DGDG, digalactosyldiacylglycerol; SQDG, sulfoquinovosyldiacylglycerol; PG, phosphatidylglycerol; PE, phosphatidylethanolamine; PC, phosphatidylcholine; PI, phosphatidylinositol; $\mathrm{PS}$, phosphatidylserine. Data are means $\pm \mathrm{SE}$ of five biological replicates. Statistical significance was calculated using ANOVA with post hoc Dunnett tests vs WT control: *, $P<0.05$; **, $P<0.01$. reached in induced SYN lines $\left(1.3 \mathrm{nmol} \mathrm{\textrm {mg } ^ { - 1 }}\right.$ dry cell weight) are similar to those reached in E. coli $\left(1.2-3 \mathrm{nmol} \mathrm{mg}^{-1}\right.$ dry cell weight) during the stringent response (Riesenberg, 1985; Rodionov \& Ishiguro, 1995). If we assume that total GTP content is similar between species, then these concentrations of ppGpp (representing 600\% of the total GTP) are considerably higher than those observed in Arabidopsis overexpressing a similar ( $\mathrm{p}$ ) ppGpp synthetase (9\% of total GTP) (Sugliani et al., 2016). This may be a result of differences between unicellular and multicellular organisms, or the capacity of the cell to control ppGpp concentrations. These high ppGpp concentrations did not lead to cell death or complete growth arrest (Fig. 5; Table S3), suggesting that ppGpp does not cause general toxicity. Interestingly, the concentrations of GTP were very similar in all lines, indicating that ppGpp synthesis does not deplete the cellular GTP pool. This result resembles the situation in Arabidopsis ppGpp overaccumulating lines (Bartoli et al., 2020) and contrasts with Grampositive bacteria, where (p)ppGpp regulates transcription by decreasing the GTP pool in the cell (Krasny \& Gourse, 2004).

We also detected ppGpp in WT cells and discovered conditions that cause ppGpp concentrations to increase (Fig. S1), although not to the concentrations measured in SYN lines. Low ppGpp concentrations could be detected in WT cells under normal growth conditions. These ppGpp concentrations correspond to $0.25 \%$ of total GTP, which is similar to Arabidopsis where ppGpp accumulates to $0.36 \%$ of total GTP under normal growth conditions (Bartoli et al., 2020). While nitrogen deprivation did not affect ppGpp concentrations, extended dark treatment caused a four-fold increase in WT and SYN control lines (Fig. S1). Dark treatment also causes an increase in ppGpp concentrations in Arabidopsis in a $\mathrm{Ca}^{2+}$-dependent RSH (CRSH)-dependent manner (Ihara et al., 2015; Ono et al., 2020). However, P. tricornutum lacks a direct orthologue of CRSH (Avilan et al., 2019), suggesting differences in the underlying mechanism controlling (p)ppGpp synthesis in the dark. The higher concentration of ppGpp observed in SYN lines than in the WT under the conditions tested raises the possibility that concentrations of ppGpp reached in SYN might not occur naturally in diatoms. While the overaccumulation of ppGpp could cause nonphysiological effects, several previous studies have successfully used lines overaccumulating ppGpp to identify targets of ppGpp signalling in plants and bacteria (Schreiber et al., 1991; Hesketh et al., 2001; Maekawa et al., 2015; Sugliani et al., 2016). We find that the major effects of ppGpp accumulation in P.tricornutum are similar to those in plants (Fig. 4), and that some effects are less severe or absent, such as for Rubisco and Chl loss (Figs 3, 4). Furthermore, while we observe strong effects on growth in P. tricornutum (Fig. 2), this does not appear to be attributable to general toxicity, as discussed earlier. Future studies will extend our work by identifying the natural range of ppGpp concentrations, and testing the physiological roles of ppGpp accumulation by the creation of mutants lacking the ability to synthesize ppGpp. 
Table 1 Major groups of proteins showing differential accumulation in response to guanosine penta- and tetraphosphate (ppGpp)accumulation in Phaeodactylum tricornutum.

\begin{tabular}{|c|c|c|c|}
\hline $\begin{array}{l}\text { Accession } \\
\text { number }\end{array}$ & Description & $\begin{array}{l}\log _{2}(\text { fold- } \\
\text { change) }\end{array}$ & $\begin{array}{l}\text { Cellular } \\
\text { localization }\end{array}$ \\
\hline \multicolumn{4}{|c|}{ Protein protection, protein quality control and chaperones } \\
\hline B7G195 & HSP20-like chaperone & 8.83 & \\
\hline B7G704 & Chaperon ClpB (HSP100) & 7.71 & \\
\hline B5Y3Y4 & HSP20-like chaperone & 7.15 & SP \\
\hline B7FXQ8 & HSP20-like chaperone & 5.98 & \\
\hline B7FUC8 & Chaperon ClpB (HSP100) & 5.89 & \\
\hline B7G6X2 & Von Willebrand factor & 5.86 & \\
\hline B7GAC9 & $\begin{array}{l}\text { Peptidyl-prolyl cis-trans } \\
\text { isomerase }\end{array}$ & 5.45 & \\
\hline B5Y4C1 & HSP20-like chaperone & 5.24 & \\
\hline B7G3Y2 & HSP70 & 5.20 & SP \\
\hline B5Y472 & HSP20-like chaperone & 4.96 & \\
\hline B7FSL4 & Lon protease & 4.71 & M \\
\hline B7G9V1 & Von Willebrand factor & 4.69 & \\
\hline B7GCE9 & HSP70 & 4.21 & SP \\
\hline B7S4A8 & GrpE, HSP90 cofactor & 2.83 & $C$ \\
\hline B7FQL4 & Armet protein & 2.69 & \\
\hline B7FWW7 & $\begin{array}{l}\text { Heat shock chaperonin-binding } \\
\text { STI1 }\end{array}$ & 2.48 & $\mathrm{C}$ \\
\hline B7FRV0 & $\begin{array}{l}\text { Chaperone protein DnaJ } \\
\text { (HSP40) }\end{array}$ & 2.39 & \\
\hline B7GEF7 & HSP9O & 2.25 & $\mathrm{C}$ \\
\hline B5Y3P1 & $\begin{array}{l}\text { Chaperone protein DnaJ } \\
\text { (HSP40) }\end{array}$ & 2.16 & $\mathrm{C}$ \\
\hline \multicolumn{4}{|l|}{ Transport } \\
\hline B7G9Z6 & $\begin{array}{l}\text { Pyrophosphate-energized } \\
\text { proton pump }\end{array}$ & 4.84 & \\
\hline B7FSN9 & Anion-transporting ATPase & 3.90 & $\mathrm{C}$ \\
\hline B7FTV6 & $\begin{array}{l}\text { Nitrate transmembrane } \\
\text { transporter }\end{array}$ & 3.85 & \\
\hline B7G5H6 & $\begin{array}{l}\text { Mitochondrial substrate/solute } \\
\text { carrier }\end{array}$ & 3.76 & SP \\
\hline B5Y4J0 & $A B C$ transporter & 3.18 & \\
\hline B7FQH7 & $\begin{array}{l}\text { Helical backbone metal receptor } \\
\text { (TroA-like domain) }\end{array}$ & 2.83 & $\mathrm{C}$ \\
\hline B7FP05 & Xanthine/uracil permease & 2.48 & \\
\hline B7GAX8 & Nucleotide transporter 1 NTT1 & 2.13 & $\mathrm{C}$ \\
\hline \multicolumn{4}{|c|}{ Amino acid metabolism } \\
\hline B7FPU3 & Glutamate synthase & 3.71 & C \\
\hline B7G3X3 & Glutamate dehydrogenase & 3.27 & \\
\hline B7G2T9 & $\begin{array}{l}\text { Thiamine pyrophosphate } \\
\text { enzyme }\end{array}$ & 2.97 & $\mathrm{C}$ \\
\hline B7FRLO & Anthranilate synthase & 2.96 & C \\
\hline B7G5H9 & Aspartate kinase & 2.63 & C \\
\hline \multicolumn{4}{|c|}{ Chlorophyll synthesis } \\
\hline B5Y3F4 & $\begin{array}{l}\text { Protoporphyrin IX magnesium } \\
\text { chelatase }\end{array}$ & 2.46 & \\
\hline \multicolumn{4}{|l|}{ Redox } \\
\hline B7G3E0 & Glutathione S-transferase & 3.36 & \\
\hline \multicolumn{4}{|c|}{ Lipid metabolism } \\
\hline B7FTR6 & Acyl-CoA dehydrogenase & 2.23 & M \\
\hline B7FRZ1 & Enoyl-CoA hydratase & 2.86 & \\
\hline \multicolumn{4}{|l|}{ Others } \\
\hline B7G2M8 & Phage shock protein A PsP & 3.45 & \\
\hline B7S452 & $\begin{array}{l}\text { Deoxyxylulose-5-phosphate } \\
\text { synthase }\end{array}$ & 2.67 & $\mathrm{C}$ \\
\hline \multicolumn{3}{|c|}{ Photosynthesis } & \\
\hline
\end{tabular}

Table 1 (Continued)

\begin{tabular}{|c|c|c|c|}
\hline $\begin{array}{l}\text { Accession } \\
\text { number }\end{array}$ & Description & $\begin{array}{l}\log _{2}(\text { fold- } \\
\text { change) }\end{array}$ & $\begin{array}{l}\text { Cellular } \\
\text { localization }\end{array}$ \\
\hline АОТОА9 & PsbH & -4.87 & $C^{*}$ \\
\hline АОТ097 & PsbD D2 & -3.20 & $C^{*}$ \\
\hline АОТОАЗ & PsbE & -3.07 & $C^{*}$ \\
\hline АОТ096 & PsbC & -2.65 & $C^{*}$ \\
\hline АОT0G9 & PsbA D1 & -2.65 & $C^{*}$ \\
\hline АОТОА4 & PsbF & -2.31 & $C^{*}$ \\
\hline B7FZ96 & $\begin{array}{l}\text { Oxygen-evolving enhancer } \\
\text { protein } 1 \text { precursor (PsbO) }\end{array}$ & -2.05 & $C^{*}$ \\
\hline \multicolumn{4}{|c|}{ Photosystem I } \\
\hline B7GCM3 & Flavodoxin & -5.28 & $\mathrm{C}$ \\
\hline АОТОА2 & $\begin{array}{l}\text { Photosystem I assembly protein } \\
\text { Ycf4 }\end{array}$ & -3.00 & $C^{*}$ \\
\hline A0TOF3 & PsaE & -2.73 & $C^{*}$ \\
\hline \multicolumn{4}{|c|}{ Calvin cycle } \\
\hline B7GE67 & $\begin{array}{l}\text { FbaC5 fructose-bisphosphate } \\
\text { aldolase class I }\end{array}$ & -6.34 & $\mathrm{C}$ \\
\hline \multicolumn{4}{|c|}{ Chloroplastic ribosomal proteins } \\
\hline АОTOI5 & Ribosomal protein S3 & -3.65 & C* \\
\hline АОТОС2 & Ribosomal protein L11 & -3.16 & $C^{*}$ \\
\hline АОТ0J8 & Ribosomal protein L13 & -3.15 & $C^{*}$ \\
\hline АОТОН8 & Ribosomal protein L3 & -2.94 & $C^{*}$ \\
\hline АотоІ1 & Ribosomal protein L2 & -2.92 & $C^{*}$ \\
\hline АОТОנ9 & Ribosomal protein S11 & -2.92 & $C^{*}$ \\
\hline АОТОI9 & Ribosomal protein L14 & -2.60 & $C^{*}$ \\
\hline АОТОЈЗ & Ribosomal protein L6 & -2.59 & $C^{*}$ \\
\hline АОТОJ1 & Ribosomal protein L5 & -2.55 & $C^{*}$ \\
\hline Q5D704 & Ribosomal protein S16 & -2.33 & $C^{*}$ \\
\hline АОТОС7 & Ribosomal protein L19 & -2.24 & $C^{*}$ \\
\hline AOTOEO & Ribosomal protein S2 & -2.20 & C* \\
\hline \multicolumn{4}{|c|}{ Fucoxanthin Chla/c-binding proteins } \\
\hline B7G8Q1 & Lhcf15 & -3.86 & $\mathrm{C}$ \\
\hline B7FR60 & Lhcx2 & -3.43 & $\mathrm{C}$ \\
\hline \multicolumn{4}{|l|}{ Transport } \\
\hline B7S437 & Bicarbonate transporter & -6.98 & \\
\hline $\mathrm{B} 7 \mathrm{G} 4 \mathrm{H} 1$ & $\begin{array}{l}\text { Sodium-dependent phosphate } \\
\text { transport protein }\end{array}$ & -5.37 & \\
\hline B7GCD8 & $\begin{array}{l}\text { Cation-transporting P-type } \\
\text { ATPase }\end{array}$ & -4.14 & \\
\hline B7G0Y4 & Ammonium transporter & -4.08 & \\
\hline B7G0V7 & Bestrophin chloride channel & -2.91 & C \\
\hline \multicolumn{4}{|c|}{ Amino acid metabolism } \\
\hline B7G5A1 & Glutamine synthetase & -2.96 & $\mathrm{C}$ \\
\hline B7GB64 & $\begin{array}{l}\text { Alanine glyoxylate } \\
\text { aminotransferase }\end{array}$ & -2.52 & \\
\hline \multicolumn{4}{|l|}{ Others } \\
\hline B7FYL2 & $\begin{array}{l}\text { Iron starvation-induced protein } \\
\text { (ISIP2A) }\end{array}$ & -6.98 & SP \\
\hline B7G9B1 & $\begin{array}{l}\text { Iron starvation-induced protein } \\
\text { (ISIP2B) }\end{array}$ & -5.27 & $\mathrm{SP}$ \\
\hline
\end{tabular}

C, chloroplast; $C^{*}$, chloroplast-encoded; HSP, heat shock protein; $M$, mitochondria; SP, presence of a signal peptide.

In plants, ppGpp accumulation inhibits photosynthesis, in particular causing a large decrease in the abundance of Rubisco, and in the ratio of PSII reaction centre (RC) to PSII LHC (Maekawa et al., 2015; Sugliani et al., 2016). Similar results were obtained in this study (Fig. 4). We found that photosynthesis was strongly inhibited in induced SYN lines, and that this was accompanied by a large drop in the PSII RC: FCP antenna ratio and 


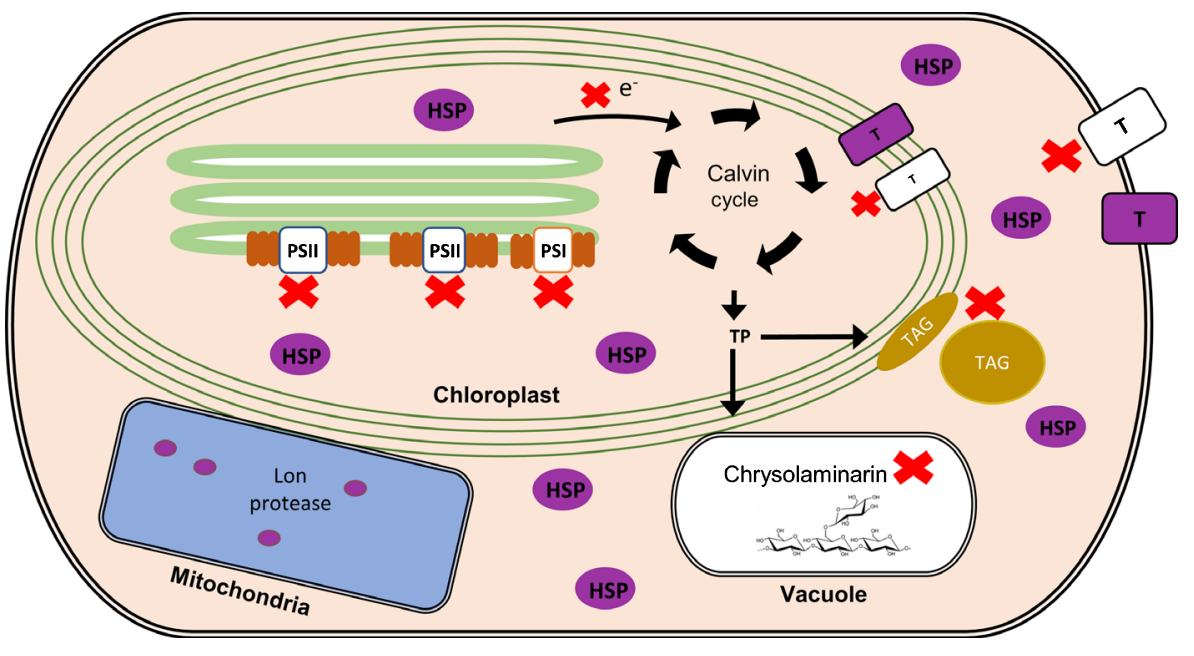

Fig. 8 Summary of the effects of guanosine penta- and tetraphosphate (ppGpp) accumulation on Phaeodactylum tricornutum. ppGpp accumulation causes a decrease in photosynthetic capacity, the chloroplast translation machinery, certain transporters, and the storage molecules triacylglycerol (TAG) and chrysolaminarin (indicated by red ' $X$ '). At the same time, ppGpp accumulation causes a large increase in the abundance of proteins involved in the protein protection response (shown in purple). TP, triose phosphate; PSII and PSI, photosystems II and I; HSP, heat shock proteins; $\mathrm{T}$, transporters. no obvious change in Rubisco concentrations (Fig. 4). Notably, these changes occur despite the significant differences in the structure and organization of the diatom FCP antenna system compared with the equivalent light-harvesting system in plants (Nagao et al., 2019; Pi et al., 2019). The drop in PSII RC, and particularly D1, in response to ppGpp accumulation could indicate an increased rate of photoinhibitory D1 destruction. However, the absence of signs of photobleaching or cell death in SYN cells suggests that ppGpp is more likely to act by interfering with D1 synthesis. The overall rate of photosynthesis was also reduced by ppGpp accumulation (Fig. 4). This is consistent with reduced protein abundance across all parts of the photosynthetic machinery, including PSII, PSI, the Calvin cycle and the bicarbonate transport through solute carrier family 4 transporter, SLC4 (Nakajima et al., 2013), as well as two carbonic anhydrases involved in the $\mathrm{CO}_{2}$-concentrating mechanism (Tables 1, S1). PSI was less widely affected than PSII, with a particularly strong reduction in concentrations of the PSI acceptor flavodoxin, while in the Calvin cycle there was a large reduction in concentrations of the key Calvin cycle enzyme, fructose bisphosphate aldolase FBAC5 (Gontero et al., 2001; Erales et al., 2008; Mininno et al., 2012). In P. tricornutum, FBAC5 is located in the pyrenoid together with two fructose bisphosphate aldolases (Allen $e t$ al., 2011). Finally, the decreased abundance of a bicarbonate transporter that is likely to supply the Calvin cycle with $\mathrm{CO}_{2}$ is reminiscent of the response of cyanobacteria to ppGpp accumulation (Hood et al., 2016). Altogether these results indicate that altered PSII architecture and reduced photosynthetic capacity are highly conserved responses to ppGpp accumulation.

In addition to its effects on photosynthesis, one of the most striking consequences of ppGpp accumulation in P. tricornutum was the strong induction of a wide range of chaperones and proteases (Table 1). Together these proteins can play an important role in protein protection by preventing protein aggregation and misfolding, and assisting with the refolding or destruction of denatured proteins (Saibil, 2013). This broad upregulation of protein quality control in response to ppGpp accumulation in $P$. tricornutum is highly reminiscent of the chloroplast unfolded protein response (cpUPR) in green algae and plants (Ramundo et al., 2014; Ramundo \& Rochaix, 2014; Llamas et al., 2017; Perlaza et al., 2019). The cpUPR can be induced by interference with chloroplast gene expression and leads to the accumulation of small HSPs, chaperones and proteases in the chloroplast and other cellular compartments. Deoxyxylulose-5-phosphate synthase (DXS), an enzyme of the chloroplastic isoprenoid pathway, accumulates during the cpUPR (Sauret-Gueto et al., 2006; Llamas et al., 2017) and we observe that it also increases in response to ppGpp (Table 1). The induction of the cpUPR along with cpUPR marker proteins strongly suggests that ppGpp inhibits chloroplast gene expression in P. tricornutum, as also observed in plants (Maekawa et al., 2015; Yamburenko et al., 2015; Sugliani et al., 2016). The marked reduction in the abundance of chloroplast-encoded proteins from PSII, PSI, and the translation machinery (Table 1) also supports this, and in the case of the translation machinery is direct evidence of reduced translational capacity.

We also found evidence that ppGpp accumulation may slow cellular ageing in P. tricornutum by restricting growth, preventing chloroplast senescence and blocking reserve compound accumulation. ppGpp accumulation caused a striking and sustained inhibition of growth (Fig. 2a) that is considerably stronger than that observed in plants (Maekawa et al., 2015; Sugliani et al., 2016). It is not currently clear whether the inhibition of growth is a result of the reduction in photosynthetic capacity or potential signalling properties of ppGpp. Shortly after induction of SYN cells, we observed the appearance of a single prominent LD next to the chloroplast, together with a small increase in TAG (Figs 5-6, S8). The appearance of the prominent $\mathrm{LD}$ could be the consequence of a metabolic overshoot following abrupt growth downregulation where, despite the concomitant downregulation of the photosynthetic machinery, the $\mathrm{CO}_{2}$ fixation rate still exceeds requirements and the resulting carbon is diverted into the synthesis of reserve compounds. Alternatively, the LD may form as a result of membrane remodelling during photosynthesis downregulation, similar to that previously shown in P. tricornutum during nutrient deprivation (Abida et al., 2015). In the stationary phase, nutrients become limiting for WT cells and this induces the synthesis of storage compounds and the degradation of photosynthetic pigments. However, we found that ppGpp 
overaccumulation prevented the degradation of $\mathrm{Chl}$ and carotenoids (Fig. 3), and even led to increased concentrations of enzymes for Chl biosynthesis (Table 1). The storage compounds TAG and chrysolaminarin also did not increase in lines overaccumulating ppGpp, and we additionally observed higher concentrations of MGDG and SQDG, consistent with a more stable chloroplast (Figs 5-6, S10, S11). Together these results suggest that ppGpp overaccumulation prevents cellular ageing by promoting a quiescent-like state. The anti-ageing effect of ppGpp in P. tricornutum contrasts with the situation in plants where ppGpp accumulation leads to reduced $\mathrm{Chl}$ concentrations, reduced chloroplast size and accelerated senescence (Maekawa et al., 2015; Sugliani et al., 2016). Together these results point to fundamental differences in (p)ppGpp signalling between multicellular and unicellular organisms (i.e. Arabidopsis vs P. tricornutum).

The accumulation of ppGpp affects diatom physiology at multiple levels and results in a quiescent-like state similar to the stringent response in bacteria that helps cells wait out stress conditions (Fig. 8). Reduction of photosynthesis and growth inhibition are common responses to stress in diatoms, suggesting that ppGpp may play an important role in stress acclimation (Litchman et al., 2003; Allen et al., 2011; Brembu et al., 2017). Other cell responses to ppGpp, such as the dramatic increase in HSP20, are also similar to those found in response to dark stress in P. tricornutum (Bai et al., 2016). However, despite these similarities, the effect of ppGpp accumulation is clearly different from those reported for nutrient stress. For example, under nitrogen starvation, there is a decrease in Chl content and an increase in storage molecules like TAG (Longworth et al., 2016). These comparisons suggest that ppGpp signalling may be an important component of a general diatom stress response pathway that acts in concert with other acclimation pathways. Altogether, our findings highlight the importance of ppGpp as a fundamental regulator of chloroplast function across different domains of life, and lead to new questions about the molecular mechanisms and roles of (p)ppGpp signalling in photosynthetic eukaryotes.

\section{Acknowledgements}

This work was supported by the Agence Nationale de la Recherche (ANR-15-CE05-0021-03, SignauxBioNRJ) and the IJPB Plant Observatory technological platform. The IJPB is supported by Saclay Plant Sciences-SPS (ANR-17-EUR-0007). LA thanks Research England for E3 funding. We thank J. Bartoli and E. Bouveret for kindly providing ${ }^{13} \mathrm{C}$-ppGpp. Electron microscopy experiments were performed on the PiCSL-FBI core facility at the IMM/IBDM, member of the France-BioImaging national research infrastructure (ANR-10-INBS-04) and the authors are especially indebted to A. Kosta, H. Le Guenno and F. Richard. Lipid analyses were performed at the HelioBiotec platform (CEA Cadarache).

\section{Author contributions}

LA, RL, BM, BF and BG conceived and planned the experiments. $S$ Citerne performed the nucleotide quantification;
$S$ Cuiné and YL-B performed and analysed the lipids; LA, CP and $\mathrm{BF}$ performed the remaining experiments. $\mathrm{LA}, \mathrm{BF}$ and $\mathrm{BG}$ contributed to the interpretation of the results. $\mathrm{LA}, \mathrm{BF}$ and $\mathrm{BG}$ wrote the manuscript. All authors provided critical feedback and helped to shape the research, analysis and manuscript.

\section{ORCID}

Luisana Avilan (D) https://orcid.org/0000-0002-4774-8564

Ben Field (iD https://orcid.org/0000-0003-2142-4606

Brigitte Gontero iD https://orcid.org/0000-0003-1731-712X

Benoit Menand (D) https://orcid.org/0000-0001-9713-5275

Yonghua Li-Beisson (D) https://orcid.org/0000-0003-1064-1816

\section{References}

Abdelkefi H, Sugliani M, Ke H, Harchouni S, Soubigou-Taconnat L, Citerne S, Mouille G, Fakhfakh H, Robaglia C, Field B. 2018. Guanosine tetraphosphate modulates salicylic acid signalling and the resistance of Arabidopsis thaliana to Turnip mosaic virus. Molecular Plant Pathology 19: 634-646.

Abida H, Dolch L-J, Meï C, Villanova V, Conte M, Block MA, Finazzi G, Bastien O, Tirichine L, Bowler C et al. 2015. Membrane glycerolipid remodeling triggered by nitrogen and phosphorus starvation in Phaeodactylum tricornutum. Plant Physiology 167: 118-136.

Allen AE, Dupont CL, Obornik M, Horak A, Nunes-Nesi A, McCrow JP, Zheng $\mathrm{H}$, Johnson DA, Hu H, Fernie AR et al. 2011. Evolution and metabolic significance of the urea cycle in photosynthetic diatoms. Nature 473: 203-207.

Apt KE, Zaslavkaia L, Lippmeier JC, Lang M, Kilian O, Wetherbee R, Grossman AR, Kroth PG. 2002. In vivo characterization of diatom multipartite plastid targeting signals. Journal of Cell Science 115: 4061-4069.

Atkinson GC, Tenson T, Hauryliuk V. 2011. The RelA/SpoT homolog (RSH) superfamily: distribution and functional evolution of ppGpp synthetases and hydrolases across the tree of life. PLoS ONE 6: e23479.

Avilan L, Puppo C, Villain A, Bouveret E, Menand B, Field B, Gontero B. 2019. RSH enzyme diversity for (p)ppGpp metabolism in Phaeodactylum tricornutum and other diatoms. Scientific Reports 9: 17682.

Bai X, Song H, Lavoie M, Zhu K, Su Y, Ye H, Chen S, Fu Z, Qian H. 2016. Proteomic analyses bring new insights into the effect of a dark stress on lipid biosynthesis in Phaeodactylum tricornutum. Scientific Reports 6: 25494.

Bartoli J, Citerne S, Mouille G, Bouveret E, Field B. 2020. Quantification of guanosine triphosphate and tetraphosphate in plants and algae using stable isotope-labelled internal standards. Talanta 219: 121261.

Benoiston AS, Ibarbalz FM, Bittner L, Guidi L, Jahn O, Dutkiewicz S, Bowler C. 2017. The evolution of diatoms and their biogeochemical functions. Philosophical Transactions of the Royal Society of London Series B: Biological sciences 372: 20160397.

Bowler C, Allen AE, Badger JH, Grimwood J, Jabbari K, Kuo A, Maheswari U, Martens C, Maumus F, Otillar RP et al. 2008. The Phaeodactylum genome reveals the evolutionary history of diatom genomes. Nature 456: 239-244.

Brembu T, Muhlroth A, Alipanah L, Bones AM. 2017. The effects of phosphorus limitation on carbon metabolism in diatoms. Philosophical Transactions of the Royal Society of London Series B: Biological Sciences 372: 20160406.

Chu L, Ewe D, Rio Bartulos C, Kroth PG, Gruber A. 2016. Rapid induction of GFP expression by the nitrate reductase promoter in the diatom Phaeodactylum tricornutum. PeerJ 4: e2344.

Cox J, Hein MY, Luber CA, Paron I, Nagaraj N, Mann M. 2014. Accurate proteome-wide label-free quantification by delayed normalization and maximal peptide ratio extraction, termed MaxLFQ. Molecular \& Cellular Proteomics 13: 2513-2526.

Dorrell RG, Gile G, McCallum G, Meheust R, Bapteste EP, Klinger CM, Brillet-Gueguen L, Freeman KD, Richter DJ, Bowler C. 2017. Chimeric origins of ochrophytes and haptophytes revealed through an ancient plastid proteome. eLife 6: e23717. 
Erales J, Avilan L, Lebreton S, Gontero B. 2008. Exploring CP12 binding proteins revealed aldolase as a new partner for the phosphoribulokinase/ glyceraldehyde 3-phosphate dehydrogenase/CP12 complex-purification and kinetic characterization of this enzyme from Chlamydomonas reinhardtii. FEBS Journal 275: 1248-1259.

Fabris M, Matthijs M, Rombauts S, Vyverman W, Goossens A, Baart GJ. 2012. The metabolic blueprint of Phaeodactylum tricornutum reveals a eukaryotic Entner-Doudoroff glycolytic pathway. The Plant Journal 70: 1004-1014.

Falciatore A, Casotti R, Leblanc C, Abrescia C, Bowler C. 1999. Transformation of nonselectable reporter genes in marine diatoms. Marine Biotechnology (NY) 1: 239-251.

Falkowski P, Scholes RJ, Boyle E, Canadell J, Canfield D, Elser J, Gruber N, Hibbard K, Hogberg P, Linder S et al. 2000. The global carbon cycle: a test of our knowledge of earth as a system. Science 290: 291-296.

Field B. 2018. Green magic: regulation of the chloroplast stress response by (p)ppGpp in plants and algae. Journal of Experimental Botany 69: 27972807.

Flori S, Jouneau PH, Bailleul B, Gallet B, Estrozi LF, Moriscot C, Bastien O, Eicke S, Schober A, Bartulos CR et al. 2017. Plastid thylakoid architecture optimizes photosynthesis in diatoms. Nature Communications 8: 15885.

Gontero B, Lebreton S, Graciet E. 2001. Multienzyme complexes involved in the Benson-Calvin cycle and in fatty acid metabolism. In: McManus MT, Laing WA, Allan AC, eds. Annual plant reviews. Sheffield, UK: Sheffield Academic Press, $120-150$.

Granum E, Myklestad SM. 2002. A simple combined method for determination of $\beta$-1,3-glucan and cell wall polysaccharides in diatoms. Hydrobiologia 477 : $155-161$.

Greenspan P, Mayer EP, Fowler SD. 1985. Nile red: a selective fluorescent stain for intracellular lipid droplets. Journal of Cell Biology 100: 965-973.

Gruber A, Kroth PG. 2017. Intracellular metabolic pathway distribution in diatoms and tools for genome-enabled experimental diatom research. Philosophical Transactions of the Royal Society of London Series B: Biological sciences 372: 20160402.

Gruber A, Rocap G, Kroth PG, Armbrust EV, Mock T. 2015. Plastid proteome prediction for diatoms and other algae with secondary plastids of the red lineage. The Plant Journal 81: 519-528.

Guillard RR, Ryther JH. 1962. Studies of marine planktonic diatoms. I. Cyclotella nana Hustedt, and Detonula confervacea (cleve) Gran. Canadian Journal of Microbiology 8: 229-239.

Harchouni S, Field B, Menand B. 2018. AC-202, a highly effective fluorophore for the visualization of lipid droplets in green algae and diatoms. Biotechnology for Biofuels 11: 120.

Hauryliuk V, Atkinson GC, Murakami KS, Tenson T, Gerdes K. 2015. Recent functional insights into the role of (p)ppGpp in bacterial physiology. Nature Reviews Microbiology 13: 298-309.

Hesketh A, Sun J, Bibb M. 2001. Induction of ppGpp synthesis in Streptomyces coelicolor A3(2) grown under conditions of nutritional sufficiency elicits actIIORF4 transcription and actinorhodin biosynthesis. Molecular Microbiology 39: 136-144.

Honoki R, Ono S, Oikawa A, Saito K, Masuda S. 2018. Significance of accumulation of the alarmone (p)ppGpp in chloroplasts for controlling photosynthesis and metabolite balance during nitrogen starvation in Arabidopsis. Photosynthesis Research 135: 299-308.

Hood RD, Higgins SA, Flamholz A, Nichols RJ, Savage DF. 2016. The stringent response regulates adaptation to darkness in the cyanobacterium Synechococcus elongatus. Proceedings of the National Academy of Sciences, USA 113: E4867-4876.

Ihara Y, Ohta H, Masuda S. 2015. A highly sensitive quantification method for the accumulation of alarmone ppGpp in Arabidopsis thaliana using UPLCESI-qMS/MS. Journal of Plant Research 128: 511-518.

Imamura S, Nomura Y, Takemura T, Pancha I, Taki K, Toguchi K, Tozawa Y, Tanaka K. 2018. The checkpoint kinase TOR (target of rapamycin) regulates expression of a nuclear-encoded chloroplast RelA-SpoT homolog (RSH) and modulates chloroplast ribosomal RNA synthesis in a unicellular red alga. The Plant Journal 94: 327-339.
Ito D, Ihara Y, Nishihara H, Masuda S. 2017. Phylogenetic analysis of proteins involved in the stringent response in plant cells. Journal of Plant Research 130: 625-634.

Jallet D, Xing D, Hughes A, Moosburner M, Simmons MP, Allen AE, Peers G. 2020. Mitochondrial fatty acid $\beta$-oxidation is required for storage-lipid catabolism in a marine diatom. New Phytologist 228: 946-958.

Jensen E, Clement R, Maberly SC, Gontero B. 2017. Regulation of the CalvinBenson-Bassham cycle in the enigmatic diatoms: biochemical and evolutionary variations on an original theme. Philosophical Transactions of the Royal Society of London Series B: Biological sciences 372: 20160401.

Jeong JY, Yim HS, Ryu JY, Lee HS, Lee JH, Seen DS, Kang SG. 2012. One-step sequence- and ligation-independent cloning as a rapid and versatile cloning method for functional genomics studies. Applied and Environment Microbiology 78: 5440-5443.

Joly N, Engl C, Jovanovic G, Huvet M, Toni T, Sheng X, Stumpf MP, Buck M. 2010. Managing membrane stress: the phage shock protein (Psp) response, from molecular mechanisms to physiology. FEMS Microbiology Reviews 34: 797-827.

Krasny L, Gourse RL. 2004. An alternative strategy for bacterial ribosome synthesis: Bacillus subtilis rRNA transcription regulation. EMBO Journal 23: 4473-4483.

Kroth PG. 2007. Genetic transformation: a tool to study protein targeting in diatoms. In: Giezen VD, ed. Protein Targeting Protocols. 2 ed. Methods in Molecular Biology. Totowa, NJ: Humana Press Inc., 257-269.

Launay H, Huang W, Maberly SC, Gontero B. 2020. Regulation of carbon metabolism by environmental conditions: a perspective from diatoms and other chromalveolates. Frontiers in Plant Science 11.

Lavoie I, Hamilton PB, Morin S, Kim Tiam S, Kahlert M, Gonçalves S, Falasco E, Fortin C, Gontero B, Heudre D et al. 2017. Diatom teratologies as biomarkers of contamination: Are all deformities ecologically meaningful? Ecological Indicators 82: 539-550.

Legeret B, Schulz-Raffelt M, Nguyen HM, Auroy P, Beisson F, Peltier G, Blanc G, Li-Beisson Y. 2016. Lipidomic and transcriptomic analyses of Chlamydomonas reinhardtii under heat stress unveil a direct route for the conversion of membrane lipids into storage lipids. Plant, Cell \& Environment 39: 834-847.

Lepetit B, Goss R, Jakob T, Wilhelm C. 2012. Molecular dynamics of the diatom thylakoid membrane under different light conditions. Photosynthesis Research 111: 245-257.

Levitan O, Dinamarca J, Hochman G, Falkowski PG. 2014. Diatoms: a fossil fuel of the future. Trends in Biotechnology 32: 117-124.

Litchman E, Steiner D, Bossard P. 2003. Photosynthetic and growth responses of three freshwater algae to phosphorus limitation and daylength. Freshwater Biology 48: 2141-2148.

Liu X, Hempel F, Stork S, Bolte K, Moog D, Heimerl T, Maier UG, Zauner S. 2016. Addressing various compartments of the diatom model organism Phaeodactylum tricornutum via sub-cellular marker proteins. Algal Research 20: 249-257.

Llamas E, Pulido P, Rodriguez-Concepcion M. 2017. Interference with plastome gene expression and Clp protease activity in Arabidopsis triggers a chloroplast unfolded protein response to restore protein homeostasis. PLoS Genetics 13: e1007022.

Longworth J, Wu D, Huete-Ortega M, Wright PC, Vaidyanathan S. 2016. Proteome response of Phaeodactylum tricornutum, during lipid accumulation induced by nitrogen depletion. Algal Research 18: 213-224.

Maekawa M, Honoki R, Ihara Y, Sato R, Oikawa A, Kanno Y, Ohta H, Seo M, Saito K, Masuda S. 2015. Impact of the plastidial stringent response in plant growth and stress responses. Nature Plants 1: 15167.

Medlin LK. 2016. Evolution of the diatoms: major steps in their evolution and a review of the supporting molecular and morphological evidence. Phycologia 55: 79-103.

Mininno M, Brugiere S, Pautre V, Gilgen A, Ma S, Ferro M, Tardif M, Alban C, Ravanel S. 2012. Characterization of chloroplastic fructose 1,6bisphosphate aldolases as lysine-methylated proteins in plants. Journal of Biological Chemistry 287: 21034-21044.

Nagao R, Kato K, Suzuki T, Ifuku K, Uchiyama I, Kashino Y, Dohmae N, Akimoto S, Shen JR, Miyazaki N et al. 2019. Structural basis for energy harvesting and dissipation in a diatom PSII-FCPII supercomplex. Nature Plants 5: 890-901. 
Nakajima K, Tanaka A, Matsuda Y. 2013. SLC4 family transporters in a marine diatom directly pump bicarbonate from seawater. Proceedings of the National Academy of Sciences, USA 110: 1767-1772.

Nomura Y, Izumi A, Fukunaga Y, Kusumi K, Iba K, Watanabe S, Nakahira Y, Weber AP, Nozawa A, Tozawa Y. 2014. Diversity in guanosine $3^{\prime}, 5^{\prime}$ bisdiphosphate (ppGpp) sensitivity among guanylate kinases of bacteria and plants. Journal of Biological Chemistry 289: 15631-15641.

Ono S, Suzuki S, Ito D, Tagawa S, Shiina T, Masuda S. 2020. Plastidial (p) ppGpp synthesis by the $\mathrm{Ca}^{2+}$-dependent RelA-SpoT homolog regulates the adaptation of chloroplast gene expression to darkness in Arabidopsis. Plant and Cell Physiology 61: 2077-2086.

Perlaza K, Toutkoushian H, Boone M, Lam M, Iwai M, Jonikas MC, Walter P, Ramundo S. 2019. The Mars1 kinase confers photoprotection through signaling in the chloroplast unfolded protein response. eLife 8: e49577.

Pi X, Zhao S, Wang W, Liu D, Xu C, Han G, Kuang T, Sui SF, Shen JR. 2019. The pigment-protein network of a diatom photosystem II-light-harvesting antenna supercomplex. Science 365: eaax4406.

Prioretti L, Avilan L, Carriere F, Montané M, Field B, Gregori G, Menand B, Gontero B. 2017. The inhibition of TOR in the model diatom Phaeodactylum tricornutum promotes a get-fat growth regime. Algal Research 26: 265-274.

Prioretti L, Carriere F, Field B, Avilan L, Montané M-H, Menand B, Gontero B. 2020. Targeting TOR signaling for enhanced lipid productivity in algae. Biochimie 169: 12-17.

Ramundo S, Casero D, Muhlhaus T, Hemme D, Sommer F, Crevecoeur M, Rahire M, Schroda M, Rusch J, Goodenough U et al. 2014. Conditional depletion of the Chlamydomonas chloroplast $\mathrm{ClpP}$ protease activates nuclear genes involved in autophagy and plastid protein quality control. Plant Cell 26 : 2201-2222.

Ramundo S, Rochaix JD. 2014. Chloroplast unfolded protein response, a new plastid stress signaling pathway? Plant Signal Behaviour 9: e972874

Riesenberg D. 1985. A radioimmunoassay for (p)ppGpp and its application to Streptomyces hygroscopicus. Journal of Basic Microbiology 25: 127-140.

Ritchie RJ. 2006. Consistent sets of spectrophotometric chlorophyll equations for acetone, methanol and ethanol solvents. Photosynthesis Research 89: 27-41.

Roding A, Boekema E, Buchel C. 2018. The structure of FCPb, a lightharvesting complex in the diatom Cyclotella meneghiniana. Photosynthesis Research 135: 203-211.

Rodionov DG, Ishiguro EE. 1995. Direct correlation between overproduction of guanosine 3',5'-bispyrophosphate (ppGpp) and penicillin tolerance in Escherichia coli. Journal of Bacteriology 177: 4224-4229.

Saibil H. 2013. Chaperone machines for protein folding, unfolding and disaggregation. Nature Reviews Molecular Cell Biology 14: 630-642.

Sambrook J, Fritsch E, Maniatis T. 1989. Molecular Cloning: a Laboratory Manual. ColdSpring Harbor, NY, USA: Cold Spring Harbor Laboratory Press.

Santin YG, Doan T, Lebrun R, Espinosa L, Journet L, Cascales E. 2018. In vivo TssA proximity labelling during type VI secretion biogenesis reveals TagA as a protein that stops and holds the sheath. Nature Microbiology 3: 1304-1313.

Sauret-Gueto S, Botella-Pavia P, Flores-Perez U, Martinez-Garcia JF, San Roman C, Leon P, Boronat A, Rodriguez-Concepcion M. 2006. Plastid cues posttranscriptionally regulate the accumulation of key enzymes of the methylerythritol phosphate pathway in Arabidopsis. Plant Physiology 141: 7584.

Schreiber G, Metzger S, Aizenman E, Roza S, Cashel M, Glaser G. 1991. Overexpression of the relA gene in Escherichia coli. Journal of Biological Chemistry 266: 3760-3767.

Siaut M, Cuine S, Cagnon C, Fessler B, Nguyen M, Carrier P, Beyly A, Beisson F, Triantaphylides C, Li-Beisson Y et al. 2011. Oil accumulation in the model green alga Chlamydomonas reinhardtii: characterization, variability between common laboratory strains and relationship with starch reserves. $B M C$ Biotechnology 11: 7.

Siaut M, Heijde M, Mangogna M, Montsant A, Coesel S, Allen A, Manfredonia A, Falciatore A, Bowler C. 2007. Molecular toolbox for studying diatom biology in Phaeodactylum tricornutum. Gene 406: 23-35.

Steinchen W, Bange G. 2016. The magic dance of the alarmones (p)ppGpp. Molecular Microbiology 101: 531-544.

Sugliani M, Abdelkefi H, Ke H, Bouveret E, Robaglia C, Caffarri S, Field B. 2016. An ancient bacterial signaling pathway regulates chloroplast function to influence growth and development in Arabidopsis. Plant Cell 28: 661-679.

Suzuki E, Suzuki R. 2013. Variation of storage polysaccharides in phototrophic microorganisms. Journal of Applied Glycoscience 60: 21-27.

Takahashi K, Kasai K, Ochi K. 2004. Identification of the bacterial alarmone guanosine 5'-diphosphate 3'-diphosphate (ppGpp) in plants. Proceedings of the National Academy of Sciences, USA 101: 4320-4324.

Uthappa UT, Brahmkhatri V, Sriram G, Jung HY, Yu J, Kurkuri N, Aminabhavi TM, Altalhi T, Neelgund GM, Kurkuri MD. 2018. Nature engineered diatom biosilica as drug delivery systems. Journal of Controlled Release 281: 70-83.

Vardi A, Bidle KD, Kwityn C, Hirsh DJ, Thompson SM, Callow JA, Falkowski P, Bowler C. 2008. A diatom gene regulating nitric-oxide signaling and susceptibility to diatom-derived aldehydes. Current Biology 18: 895-899.

Wang LJ, Fan Y, Parsons RL, Hu GR, Zhang PY, Li FL. 2018. A rapid method for the determination of fucoxanthin in diatom. Marine Drugs 16: 33.

Yamburenko MV, Zubo YO, Borner T. 2015. Abscisic acid affects transcription of chloroplast genes via protein phosphatase 2C-dependent activation of nuclear genes: repression by guanosine- $-3^{\prime}-5^{\prime}$-bisdiphosphate and activation by sigma factor 5. The Plant Journal 82: 1030-1041.

\section{Supporting Information}

Additional Supporting Information may be found online in the Supporting Information section at the end of the article.

Fig. S1 ppGpp concentrations in SYN and wild-type cells under different conditions.

Fig. S2 Protein profiles of SYN and controls at $2 \mathrm{~d}$ after induction.

Fig. S3 Volcano plot showing the changes in protein expression at $2 \mathrm{~d}$ after induction.

Fig. S4 SYN is targeted to chloroplasts by the AtpC chloroplast targeting sequence.

Fig. S5 Growth curves of different $\mathrm{SYN}$ and $\mathrm{SYN}{ }^{\mathrm{D}>\mathrm{G}}$ lines.

Fig. S6 Pigment absorption spectra.

Fig. S7 Photosynthetic parameters of SYN lines at different time points after induction.

Fig. S8 Electron micrographs of SYN cells at $2 \mathrm{~d}$ after induction.

Fig. S9 Comparison of lipid droplet phenotypes in $S Y N^{D>G}$ and wild-type cells.

Fig. S10 Chrysolaminarin concentrations in SYN lines.

Fig. S11 Effect of ppGpp on polar lipid and fatty acid composition at $2 \mathrm{~d}$ post-induction.

Methods S1 Expanded methods describing transformation, electron microscopy and proteomics experiments.

Table S1 List of different primers used in this study. 
Table S2 List of differentially expressed proteins in SYN lines vs controls.

Table S3 Growth and phenotype of SYN cells during prolonged induction.
Please note: Wiley Blackwell are not responsible for the content or functionality of any Supporting Information supplied by the authors. Any queries (other than missing material) should be directed to the New Phytologist Central Office.

\section{About New Phytologist}

- New Phytologist is an electronic (online-only) journal owned by the New Phytologist Foundation, a not-for-profit organization dedicated to the promotion of plant science, facilitating projects from symposia to free access for our Tansley reviews and Tansley insights.

- Regular papers, Letters, Viewpoints, Research reviews, Rapid reports and both Modelling/Theory and Methods papers are encouraged. We are committed to rapid processing, from online submission through to publication 'as ready' via Early View our average time to decision is $<26$ days. There are no page or colour charges and a PDF version will be provided for each article.

- The journal is available online at Wiley Online Library. Visit www.newphytologist.com to search the articles and register for table of contents email alerts.

- If you have any questions, do get in touch with Central Office (np-centraloffice@lancaster.ac.uk) or, if it is more convenient, our USA Office (np-usaoffice@lancaster.ac.uk)

- For submission instructions, subscription and all the latest information visit www.newphytologist.com 